\title{
Household Food Security and Nutrition Analysis Using a Farm Simulation Model (FARMSIM): Case Study of Robit in Amhara Region, Ethiopia
}

\author{
Jean-Claude Bizimana, ${ }^{1, *}$ James W. Richardson ${ }^{2}$ and Neville P. Clarke ${ }^{3}$
}

\begin{abstract}
The majority of the world's undernourished people are located in developing countries, including Sub-Saharan Africa. One way of combatting food insecurity is to increase food production and promote the consumption of balanced diets. This study evaluates the impact of small-scale irrigation technologies on food security and nutrition through food production and consumption in Robit village, Amhara region of Ethiopia. Household survey data and a farm level economic and nutrition simulation model (FARMSIM) is used to perform the analysis. A baseline scenario with minimal irrigation and current food consumption is compared to four alternative irrigation scenarios producing vegetables and fodder and aligned with four different food consumption patterns. Nutrition and food security evaluation is based on the intake per day and adult equivalent of calories, proteins, fat, iron, calcium and vitamin A. Food consumption in the baseline scenario indicates a satisfactory intake of calories from a cereal-based diet dominated by teff and maize but limited in consumption of fruits, vegetables, pulses and animal source foods. The alternative scenario under vegetables and fodder production shows the highest nutritional and economic outcomes allowing the household to purchase supplemental food items such as milk, meat, and eggs to meet nutritional needs.
\end{abstract}

Keywords: Food security; Simulation; Irrigation; Risk; Nutrition; JEL classification: O1, O2, O3.

Received: 9 November 2020; Accepted: 19 November 2020.

Article type: Research article.

\section{Background}

Global food security remains an important topic of discussion for the political and development agenda of many governments, especially those in the developing world where the vast majority of the world's undernourished people are located. ${ }^{[1,2]}$ The second of the seventeen Sustainable Development Goals (SDG 2), as adopted in 2015 by the United Nations (UN), calls on countries to end hunger, achieve food security and improved nutrition, and promote sustainable

${ }^{I}$ Agricultural \& Food Policy Center, Department of Agricultural Economics, Texas A\&M University, 600 John Kimbrough Blvd, College Station, TX 77843-2124

2 Agricultural \& Food Policy Center, Department of Agricultural Economics, Texas A\&M University, 600 John Kimbrough Blvd, College Station, TX 77843.

${ }^{3}$ Vice Chancellor for Agriculture Office, Texas A\&M University; 534 John Kimbrough Blvd, College Station, Texas 77843-2120.

*Email: bizimanatex@tamu.edu (J.C Bizimana) agriculture by year 2030..$^{[1,3]}$ The 2016 Global Hunger Index (GHI) report ${ }^{[1]}$ shows that progress has been made since 2000 to reduce the proportion of hungry people in developing countries where the level of hunger was cut by 29 percent. However, its levels are still alarming especially in Africa south of the Sahara and South Asia, with most of the seven countries with severe GHI scores being in sub-Saharan Africa. A joint report by several UN agencies indicates that the number of people affected by food insecurity worldwide started rising in 2014 and sub-Saharan Africa emerged as having the highest prevalence of undernourishment with 22.7 percent of its population affected in 2016. ${ }^{[4]}$

Some of the factors that may have contributed to the recent increase in food insecurity include the reduction in food availability and increase in food prices in regions affected by climatic shocks from El-Nino and La Nina phenomenon as well as the increase in number of conflicts.

A widely accepted definition of food security describes it as a state "when all people at all times, have physical, social and economic access to sufficient, safe and nutritious food to 
meet their dietary needs and food preference for an active and healthy life". ${ }^{[2]}$ This definition covers many of the dimensions and components of food security, including temporality and shocks; physical, social, and economic access to food as well as sufficient quantity and quality of food to meet nutritional requirements.

In addition to hunger and undernourishment which are characterized by a lack of minimum required caloric intake (1800 Calories/day/person), other aspects of food insecurity that are often overlooked relate to micronutrient deficiency or "hidden hunger". ${ }^{[7]}$ While hunger globally affects around 805 million people, hidden hunger is estimated to affect two billion people around the world. ${ }^{[3]} \mathrm{A}$ chronic deficiency in minerals and vitamins can have long term and serious health consequences that include child and maternal mortality, physical disabilities, weakened immune systems, and intellectual deficits. ${ }^{[8,9]}$ In developing countries a combination of deficiency for several micronutrients occur together and account for about 7 percent of global disease each year with the most notable deficiencies being in zinc and vitamin $\mathrm{A} .{ }^{[8,10]}$ The micronutrient deficiency or hidden hunger is partly due to continuous consumption of cereal-based diets that lack diversity. Increasing dietary diversity to provide a balanced diet, that include fruits and vegetables, is one of the most effective ways to sustainably prevent food insecurity and malnutrition. ${ }^{[9,11]} \mathrm{A}$ balanced diet is a diverse diet which provides all the nutrients a person requires, without going over the recommended daily calorie intake. ${ }^{[12]}$

Even though civil wars and disease may have contributed to issues of food security in sub-Saharan Africa, other types of threats linked to frequent and unpredictable climate-related shocks pose serious risks to the stability and food security of many households in SSA and beyond. ${ }^{[3,13]}$ For instance, recurrent drought and episodes of famine are plaguing several parts of the Horn of Africa, including Ethiopia. In recent years, food insecurity and the need for food aid have increased in Ethiopia due to severe drought caused by poor rains (e.g. 2010-2011 and 2015) and have put approximately 7.5 million people at risk, worsening the food security status in households. ${ }^{[13-14]}$ Several studies across Ethiopia which indicate that the majority of poor people live in food-deficit areas and more often on a diet predominantly comprised of cereals, also point to a high prevalence of wasting among children due to undernutrition. ${ }^{[3,15-17]}$

Although the issue of food security is multifaceted, part of the solution to combat it is to increase the food production and promote the consumption of balanced diets specifically in regions of food deficiency. Given that the majority of the Ethiopia population depends on agriculture, broad-based agriculture growth, diversification of food crops and livestock production, are key to reducing poverty and increasing food security. However, to achieve this goal, there is a need to reduce the productivity gap between the old agricultural technologies that still exist in Ethiopia and modern technology. ${ }^{[16,18]}$ One area of improvement could be in irrigated agriculture as many households in SSA rely on rain-fed agriculture to mainly produce cereals for food with limited nutritional value and low market value for enhancing income. ${ }^{[6]}$ Irrigation is one of the interventions that can increase crop productivity and reduce malnutrition since water is most often a limiting factor in diversifying crop and livestock production. ${ }^{[19,20]}$

Due to recurrent drought episodes observed in Ethiopia, small-scale irrigation (SSI) technologies can be considered as interventions to grow vegetables and fodder during the dry season and also be used for supplemental irrigation when the rain season is delayed or cut short. Therefore the adoption and proper use of irrigation technologies can contribute to an increase in the quantity and variety of crops produced and consumed as it allows households to have multiple cropping seasons (dry and rainy seasons). ${ }^{[6,21]}$ This is very critical for countries located in sub-Saharan Africa where only about 6 percent of the cultivated area is irrigated, a lower irrigation percentage compared to countries from other regions of the world. ${ }^{[6]}$ A research study on water and food security estimated that tripling the irrigated area in Africa by 2050 would substantially increase the food supply and decrease net imports of cereal food. ${ }^{[22]}$ In Ethiopia, farmers using irrigation produced crops twice, and sometimes even three times, per year. ${ }^{[20]}$

Most of the time crops benefiting from irrigation expansion are vegetables grown during the dry season, and their consumption and nutritional benefits are numerous for household families. ${ }^{[6,11]}$ The implications of using SSI technologies for household nutrition vary according to the types of crops grown and consumed. For example, the consumption of green leafy vegetables is known to help reduce anemia due to its high iron content while the consumption of vitamin A rich foods (pumpkin, orange-fleshed potatoes) can significantly improve vision and immunity. ${ }^{[11]}$ Improved gardening practices from traditional practices, through the establishment of home gardening can allow year-round production of vegetables increasing their quantity, variety and consumption at household level. ${ }^{[11,23]}$

Irrigation systems can also improve the availability of food products of animal origin due to potential increases in income to purchase meat, milk, and eggs as well as improved livestock productivity from improved animal feeds. ${ }^{[6]}$ Milk, eggs, and occasional meat from the animals can help families, especially children, increase micronutrient and protein intake, while the manure produced by animals can be used to improve the fertility of vegetable gardens' soil. Animal-source foods have a high energy density and are good sources of high-quality protein, readily available iron and zinc, as well as vitamins B6, B12, B2, vitamin A and all micronutrients frequently limited in plant-based diets. ${ }^{[25]}$

The adoption and use of irrigation technologies has shown as well potential impact on poverty reduction and income generation and can play an important role in food costs reduction. ${ }^{[22,26]}$ Surplus crops from irrigated agriculture can be 
sold and resulting revenues used to buy food items needed to complement nutritional needs at the household. Sale of vegetables, fruits and animal-source products, produced from irrigated agriculture, are normally marketable and high profitable products, and an important source of income for households. ${ }^{[6,27]}$ A research study on the impacts of small-scale irrigation on household dietary diversity in Ethiopia and Tanzania showed that potential pathways to food diversity is most likely through increased income rather than directly through production. ${ }^{[20]}$ The economic gains from irrigation come as well through labor hiring as irrigation activities require more labor than rain-fed farming.

Combating food insecurity in developing countries, especially micronutrient deficiency, requires very specific and food-based approaches. ${ }^{[7,25]}$ Early-on solutions to fight micronutrient deficiency consisted of supplementation to households, but revealed to be less feasible and sustainable. The promotion and implementation of food-based strategy to sustainably improve nutrition has been advocated and some pilot studies had already shown promising results. For instance, reinforcing local food systems that are mainly cereal based with homestead gardening (fruit and vegetables) and smallscale animal husbandry showed preliminary signs of nutrition improvement at the household level in Africa and Asia. ${ }^{[7,11,23,24,31]}$

This article seeks to contribute to existing literature on food security by showing the potential of local food production systems to sustainably contribute to the improvement of food security and nutrition in Ethiopia. In this regard a farm level economic and nutrition simulation model (FARMSIM) is used to evaluate the impacts of small-scale irrigation (SSI) technologies and fertilizers on household food security and nutrition in Robit kebele, Ethiopia. The model takes into account increased food production and income from adopting improved agricultural technologies and its impact on nutrition through food production and purchase. The evaluation of nutrition in FARMSIM reflects more the concept of food security in terms of accessibility and availability of food and nutrients at the household. The objectives of this study are two-fold:

1) Analyze the impacts of irrigation technologies on quantity and variety of food crops produced and consumed at the household and its impact on nutrition.

2) Evaluate the impacts of income and profit increase at the household from sale of surplus crop production on nutrition through the purchase of supplemental food items.

The rest of the paper is organized in three sections. First, we offer a description of the farm economic and nutrition model (FARMSIM) ${ }^{\mathrm{ii}}$ followed by the presentation of the base and alternative scenarios analyzed in the study. Then, we present the results and discussion, followed by the conclusions and implications on food security and nutrition.

\section{Study area and data}

The case study was conducted in Robit kebele (village), located in Bahir Dar Zuria district (woreda), West Gojam zone in Amhara region of Ethiopia, approximately $20 \mathrm{Kms}$ from Bahir Dar town (Fig. 1). The village area has an average elevation of 1,848 masl (meter above sea level). According to the 2007 Ethiopia Census report, a total of 8,900 people were living in the village. ${ }^{[32]} \mathrm{A}$ mixed crop-livestock production is the predominant farming system in the area where the main crops grown include maize, finger millet, teff, rice, and chickpeas. ${ }^{[33]}$ Crops are grown using both rain and irrigation water. Two major cropping seasons are identified in Ethiopia: Kiremt and Bega. Kiremt is the main rainy season (JuneSeptember) during which major field crops (mainly grains) are grown and harvested in Meher season.

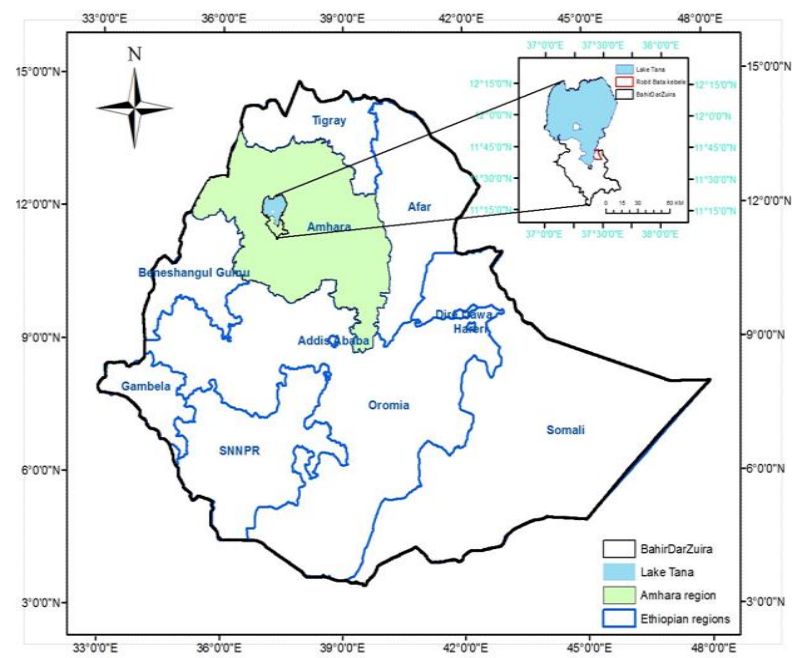

Fig. 1 Location of Robit kebele in Bahir Dar Zuria woreda, Amhara region.

Irrigated crops such as tomatoes, grass peas, chickpeas, cabbage and onions are grown during the Bega season (dry from October to January). Shallow wells are the main source of irrigation water. Most of the households keep cattle, small ruminants, poultry, and bees. Cattle are mainly raised to meet draught power requirements while milk, meat, manure, dung cake, breeding replacement stock are income sources. The majority of the milk produced is retained for home consumption, but some milk is processed into butter for sale and family consumption.

This study used mostly primary data farming information as input into the FARMSIM model. The primary data source, for the baseline scenario, consisted of one main household and community survey ${ }^{\mathrm{iii}}$ conducted in 2014 by the Livestock and Irrigation Value Chains for Ethiopian Smallholders (LIVES) project. ${ }^{[34]}$ The information from the LIVES survey was summarized according to the FARMSIM model input datasheet which requires information on crops, livestock, assets, liabilities and fixed and enterprise specific variable costs for a representative farm. To simulate a representative farm or household in Robit, each data input into the model was obtained by averaging over the sampled households drawn from the survey. Input data from the survey used households sampled in Robit kebele. The LIVES household survey 
collected data across Ethiopia on 5,004 smallholder households located in 497 rural kebeles, 72 districts, 10 zones in four highland regions of Ethiopia: Tigray, Amhara, Oromia, and Southern Nations, Nationalities and Peoples (SNNP). Twelve kebeles were selected in Bahir Dar Zuria district including Robit. The Robit sample size from which average input values were computed, comprised twelve households. Robit kebele was selected as the case study in this study due to data availability and also as one of the ILSSI sites for smallscale irrigation field experiments.

Input data for the alternative scenarios were mainly drawn from data collected in Robit between 2016 and 2017 by IWMI during the ILSSI project field interventions with local farmers on small-scale irrigation technologies. About 14 farmers participated in the field trials on improved water lifting technologies that comprised the Rope \& washer pump and pulley/bucket/tank system to grow vegetables and fodder in dry season ${ }^{\text {iv }}$. Livestock input data for the alternative scenarios were collected by ILRI during field studies on livestock nutrition and productivity. ${ }^{[35]}$ The primary data were supplemented by secondary data that included expert opinion, research articles, and reports from government and nongovernment agencies. For more details on input data and their sources, see a summary table of the primary input data sources in Appendix C3 and the Supplementary materials file.

\section{Methods}

\subsection{Farm economic and nutrition simulation model (FARMSIM)}

The farm simulation model "FARMSIM" is a Monte Carlo simulation model that simultaneously evaluates a baseline and alternative technologies for a farm. The model is programmed in Microsoft ${ }^{\circledR}$ Excel and utilizes the Simetar $\subseteq$ add-in to estimate parameters for price and yield probability distributions, simulate random variables, estimate probability distributions for key output variables (KOVs) and rank technologies. ${ }^{[36] \mathrm{v}}$

FARMSIM is programmed to recursively simulate a fiveyear planning horizon for a diversified crop and livestock farm and repeats the five-year planning horizon for 500 iterations ${ }^{\mathrm{vi}}$. The resulting 500 simulated values for each of the key output variables (KOVs) defines the empirical probability distributions to compare the baseline and alternative farming technologies. By comparing the probability distributions for the base and alternative technologies, decision makers can quantitatively analyze the probable consequences of introducing alternative farming systems.

FARMSIM is programmed to simulate a farm with up to 15 crops as well as cattle, dairy, sheep, goats, chickens, and swine annually for five years.

The farm family is modeled as the first claimant for crop and livestock production with deficit food production met through food purchases using net cash income from selling surplus crops and livestock production. Standard accounting procedures are used to calculate receipts, expenses, net cash income, and annual cash flows. The KOVs for the model can include all endogenous variables but most attention is on annual net cash income, annual ending cash reserves, net present value, benefit-cost ratio and annual family nutrient consumption of protein, calories, fat, calcium, iron, and vitamin A.

The baseline and alternative technology scenarios are simulated by FARMSIM using the same equations so the only difference in the economic and family nutrition outcomes are due to the technology differences. The FARMSIM model has four major components: crop, livestock, nutrition, and finance. Since the focus of the paper is on nutrition and food security, the nutrition component of the model is discussed; see details on the FARMSIM model components in Bizimana and Richardson. ${ }^{[37]}$

To simulate nutrition in FARMSIM, the total kilograms of each raised crop consumed by the family plus the kilograms of purchased foodstuffs are multiplied by their respective nutrient scores to calculate total calories, protein, fat, calcium, iron and vitamin A from consumed food stocks. Similar calculations are made to simulate the nutrients derived from consuming cattle, oxen, milk, butter, chickens, eggs, mutton, lamb, nannies, kids, and pig products.

Total nutrients consumed by the family from all sources, including donated food, are summed across plant and animal food stocks and compared with minimum daily recommended amounts for adults based on the Food and Agriculture Organization (FAO) minimum requirements standards. ${ }^{[38-41]}$ The average minimum daily requirements (MDR) per adult equivalent $(\mathrm{AE})$ of the six nutrients are available in the model to help determine nutrition adequacy per $\mathrm{AE}$ at the household level. See the nutrition simulation flow chart in Appendix A for graphical illustration of how the nutrition is simulated at the household level.

We used the OECD adult equivalence scale approach to estimate the number of adults in a household, which assigns weights of 1 to the first adult household member, 0.7 to each additional adult and 0.5 to each child. ${ }^{[42]}$ These weights are applied to the total number of families living in Robit to determine first, the total number of adults living in Robit. Then, the total number of adults is subtracted from the entire Robit population to compute the total number of children and their subsequent number of adult equivalents (See Supplementary materials file under "FARMSIM_Data_Entry" worksheet). Note that the fraction of crop, livestock and animal-source foods consumed by the household adult equivalents was kept constant for the baseline and alternative scenarios for all crops and livestock except the irrigated vegetables for which the fraction was adjusted to provide the needed amount and sell the remaindervii. The consumption fraction of milk, however, increased in alternative scenarios due to increase in milk production and the need for additional animal-source food by the household.

FARMSIM is capable of evaluating the nutrition status by comparing the potential for current and alternative scenarios 
to increase food nutrition after adoption of alternative agricultural technologies. The model can be used for policy analysis as it considers different crops produced and how income can be targeted to purchase specific food items designed to improve nutrition.

The quantity of the crop sold is the residual after subtracting the quantity consumed by the family and livestock viii. Family consumption and livestock feed requirements are simulated by Equation (1):

Family Consumption $_{i t}=Q F_{i} *$ No. Adult Equivalent .......(1)

$Q F_{i}$ is the minimum quantity of crop $i$ consumed per adult equivalent per year and No. Adult Equivalent is the number of adult equivalents in the farm family.

Nutrition calculations for the farm family extend FARMSIM beyond traditional farm budget and whole farm simulation models. The nutritional values for all crops and livestock products consumed by the family are simulated using FAO's nutrient values for each crop and livestock products $^{[39-40]}$ and other resources on food composition tables ${ }^{\text {ix }}$, based on their average content of protein, calories, fat, iron, calcium and vitamin A. For instance, protein intake simulation for a family is expressed as Equation (2):

Protein $_{t}=\left[\sum_{i}\right.$ (Family Consumption $_{i t}+$

Purchased Crop it $) *$ Grams of Protein /Unit of Crop i] + $\left[\sum_{j}\right.$ (Family Consumption $_{j t}+$

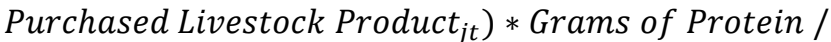

Unit of Livestock Product $\left.{ }_{j}\right]$

The protein equation is repeated for each of the remaining nutrient categories of calories, fat, iron, calcium and vitamin A. Probability that the farm family's nutritional intake exceeds the FAO recommended daily requirements is calculated annually over the 500 iterations for each of the six nutrient categories to determine the probability that a particular nutrient is not deficient. The formula for each nutrient is the same as the equation for protein as shown in Equation (3).

$P\left(\right.$ Protein $\left._{t}\right)=\sum_{s}\left(1\right.$ if Protein $_{t s} / 365>$

Daily Minimum Reg, 0 else) / 500.

\subsection{Baseline and alternative scenarios}

Data in FARMSIM is entered in parallel for the baseline and alternative scenarios. For each input variable the user must provide information for the current (baseline) and alternative farming system (scenario). The model is designed so the user can enter complete data sets for the baseline and up to 21 alternative scenarios. The scenario analysis focuses on the evaluation of the impact of improved smallholder farming technologies (irrigation, fertilizer) on crop production in the dry season as well as the impact of consuming diversified foods on nutrition at the household level.

Given that most irrigation water in Amhara is groundwater from wells, a simple and affordable water lifting technology consisting of a pulley-bucket-tank to extract and store water and a hose to use for irrigation, are considered for all alternative scenarios. Optimal and recommended fertilizer applications in ILSSI field interventions were considered as well for the alternative scenarios while current fertilizer rates from the baseline survey were used in the study (see Appendix $\mathrm{C} 1$ and Bizimana and Richardson ${ }^{[37]}$ ).

Three major cereal crops (maize, teff and millet) consistent with the cropping system in Robit and grown during the rainy season are considered in this study. In addition to cereal crops, chickpeas, potato, cabbage, tomato, fodder and napier grass are analyzed in the model (Appendix B). The main yield difference in cereals between the baseline and alternative scenarios in terms of technology input come from fertilizer application and tillage. Literature and a recent household survey carried out in Robit by the LIVES project indicate that a relatively adequate amount of fertilizer (Diammonium Phosphate or DAP and Urea), close to the recommended rates, is used by farming households (baseline scenario) in Robit for maize and millet. ${ }^{[43]}$ However, due to low fertilizer application rates for teff in the baseline scenario, increased levels of fertilizers were considered for the alternative scenarios. The increase in yield from the baseline to the alternative scenarios for millet and maize are mainly due to the deep tillage to break the hardpan soil in Robit kebele for all alternative scenarios ${ }^{\mathrm{x}}$.

With regard to potato, increased fertilizer rates but lower than the minimum recommended were applied in all alternative scenarios compared to the baseline. ${ }^{[44]}$ The same levels of fertilizers (current), but limited as well, were considered in the baseline and alternative scenarios for chickpeas since it did not show any stress for phosphorus and can fix nitrogen (see details on fertilizer rates in Appendix C1). The survey information shows as well that most of the households used stored seeds from the previous harvest for the following planting season and the use of chemicals was limited. The level of farm labor hiring for agricultural production in the baseline scenario was low since family members performed some of the agricultural tasks. However, in the alternative scenarios more hired labor was considered, especially for irrigation activities.

The irrigated crops grown during the dry season consist mainly of tomato and cabbage in the vegetable category and fodder (oats \& vetch) and napier grass in the animal feed category. The use of actual food crops to feed animals is not common as most of the animal feed comes from crop residues. Cattle were mainly fed with fodder (oats \& vetch) to increase milk and meat production. Napier was mostly produced for market sale and its income used to purchase supplemental food items needed for nutrition enhancement.

While the required fertilizer rates for tomato (Urea: 200 $\mathrm{Kgs} / \mathrm{ha}$ and DAP: $100 \mathrm{Kgs} / \mathrm{ha}$ ) were applied in the alternative scenarios, [44; ILSSI report, $2016 \mathrm{xi}]$ household survey indicated limited application of fertilizers (Urea: $56 \mathrm{Kgs} / \mathrm{ha}$; no DAP) in the baseline scenario. For cabbage, given that few households reported applying fertilizers (baseline scenario), very low amount of fertilizer compared to the recommended rates ${ }^{[45]}$ 
was considered for the baseline and alternative scenarios. Therefore, the cabbage yield difference was mainly due to the amount of irrigation water applied which sets the baseline and the alternative scenarios respectively at 50 and zero percent water stress levels.

For animal feed (fodder and napier grass), additional amounts of fertilizer to the current levels were applied to fodder (oat \& vetch) alongside the purchase of seeds in the alternative scenarios. Minimal levels of fertilizer and irrigation were applied for napier grass in both the baseline and alternative scenarios as no information on the current application was available. Details on crop inputs and yields are in Appendices $\mathrm{C} 1$ and $\mathrm{C} 2$. Following are the five scenarios and crop mix consisting of a baseline scenario with current agricultural practices and four alternative scenarios with improved small-scale irrigation and fertilizers technologies (Appendix B).

- Baseline: no or minimal irrigation + current fertilizer + current tillage

- Alt.1 (Pulley-All): optimal irrigation of vegetables, fodder and napier with pulley + fertilizer + deep tillage

- Alt.2 (Pulley_NoVeg): optimal irrigation of fodder and napier with pulley + fertilizer + deep tillage (no vegetables grown)

-Alt.3 (Pulley_NoFod): optimal irrigation of vegetables with pulley + fertilizer + deep tillage (no fodder \& napier grown)

- Alt.4 (Pulley_NoPC): optimal irrigation of vegetables, fodder and napier with pulley + fertilizer + deep tillage (no potato \& chickpeas grown)

\subsection{Livestock production technologies}

Improving animal feed resources can have a positive impact on both household income and nutrition through the production, consumption and sale of live animals and animal products. In this study, small-scale irrigation (SSI) and fertilizer technologies were used to grow and improve yields of fodder and napier grass to feed animals, and as a consequence increase the production and consumption of animal products for better nutrition and income generation. Livestock production technologies were aligned with crop production and water lifting irrigation technologies.

In the baseline scenario, fodder crops (oats \& vetch) and napier grass are grown on limited land with minimal irrigation and fertilizer applications. However, in the alternative scenarios, more land is allocated to fodder and napier due to irrigation. A portion of the total production of fodder is fed to cows and bulls $(1,600 \mathrm{Kgs} / \mathrm{head} / \mathrm{year})$ to increase the production of milk and meat while any surplus is sold to generate income. For instance, the input data information for fodder quantity produced from a single cut, based on yield $(1,400 \mathrm{Kgs} / \mathrm{ha})$ and allocated land per farm $(0.02 \mathrm{ha})$ for the baseline scenario in Robit, shows that the household uses all of the fodder production for feeding. For the alternative scenarios, yields are doubled and allocated land for fodder tripled, allowing the household to produce a surplus of fodder for sale.

Preliminary results on the calculations of meat and milk production from a single cut of fodder (oats \& vetch mix) and napier grass (Appendix D) were produced by researchers at the International Livestock Research Institute (ILRI) ${ }^{[35]}$ In this study, we assumed also an adoption rate of 60 percent by farmers for the livestock technology, doubling the 30 percent rate of adoption reported in the LIVES household survey. Following are the baseline and alternative technology scenarios for livestock production:

- Baseline: No or minimal irrigation + current animal feeding (no supplemental feed)

- Scenario 1 (ALT1): Irrigation of fodder \& napier w/pulley + supplemental fodder feeding

- Scenario 2 (ALT2): Irrigation of fodder \& napier w/pulley + supplemental fodder feeding

- Scenario 3 (ALT3): No fodder \& napier irrigation + no supplemental feeding

- Scenario 4 (ALT4): Irrigation of fodder \& napier w/pulley + supplemental fodder feeding

Based on the crop and livestock production technologies described in scenarios above (sections 3.2 and 3.3), five consumption patterns or trends aligned with the baseline and four alternative scenarios stand out. Input for the baseline scenario consumption pattern is based on the current food consumption while the alternative scenarios are based on the crop mix reflecting a variety of food groups that includes vegetable, tubers, pulse and animal products acquired through production and purchase. Following are the baseline and four alternative scenarios related to potential consumption trends aligned with the technology scenarios.

Baseline: Current food items consumed per week by a household

ALT1_All: Current consumption + All additional food items from irrigation and purchase (vegetables, potatoes \& chickpeas, animal products)

ALT2_NoVeg: Current consumption + Potato \& chickpeas + No Vegetable \& No purchase

ALT3_NoFodder: Current consumption + Potato \& chickpeas + Limited raised animal products + Purchase

ALT4_NoPotato \& Chickpeas: Current consumption + Vegetables + animal products + No Potato \& chickpeas + Purchase

\subsection{Micro and macro level assumptions}

First, to show the full potential of technology adoption, we assumed that the simulated alternative farming technologies are fully adopted. This is guided by the high adoption rate of farming technologies which can go up to 70 percent of households adopting fertilizer and seed for cereals as indicated in the LIVES household survey. As for livestock production technologies, we assumed a 60 percent adoption rate which is two times higher the original 30 percent adoption rate reported 
in the household survey. No scientific basis guided this choice apart from the assumption of a scenario where the current adoption rate is doubled and the fact that livestock technologies are generally slow to adopt than crop technologies.

Second, since the farmer's profit depends on the amount of crop, livestock and livestock products sold at the markets, accessibility to markets by the farmers is of paramount importance. Access to markets depends in part on the existence of road and market infrastructure in the Bahir Dar Zuria district where a survey by the International Water Management Institute (IWMI) in 2015 indicated an average of $1.4 \mathrm{~km}(0.9$ miles) distance to market (See Supplementary materials). With regard to market existence and operations, a market research report shows that the demand for milk at Bahir Dar surrounding markets was higher than the supply. ${ }^{[33]}$ The report indicates as well that supplemental feeds were purchased by farmers at both local and Bahir Dar markets. To maintain quality, vegetables are often sold at the farm gate, roadside and local markets in Bahir Dar. A household survey conducted in Robit in 2017 by IWMI indicates as well that about 70 percent of the vegetables produced (mainly garlic and tomatoes) were sold by farmers at the market (See data in supplemental material). However, in many developing countries markets fail due to the lack of communication and transport infrastructure, and appropriate regulations and finance. ${ }^{\left[31,{ }^{32]}\right.} \mathrm{We}$ recognize that the issue of market access and participation is complex in these countries where several types of transaction costs come into play ${ }^{[48]}$; these forces are included in the analyses to the extent possible by using prices derived from farmer surveys rather than published country average prices.

Last, based on the above discussion on market access and preliminary simulation runs on profitability, we assume reasonably that households under profitable alternative scenarios will allocate on average 10 percent of their net profit to purchase supplemental foodstuff of animal source especially eggs, milk, chicken and beef to improve nutrition. The choice of this number is not based on any scientific evidence except an insight from other related work (e.g Alaofe et al., 2016) that families do not necessarily allocate much of their profit to purchase food as there are other competing household needs such as school fees, health care, utilities, clothes etc.

\section{Simulation results}

In general, adoption and proper use of agricultural technologies leads to an increase in the amount and variety of crops produced. The implications for household nutrition vary according to the types of crops grown and consumed. However, surplus crops can be sold and resulting revenues can be used to buy food items needed to complement nutrition. This study will consider both avenues of improving nutrition through production and purchase.

\subsection{Current status of food consumption and nutrition}

An assessment of the current situation (baseline scenario) of food consumption by a representative household in Robit kebele is summarized from the survey data collected by the LIVES project ${ }^{\mathrm{xii}}$ (Appendix E1). The summary results show on average that a household in Robit neighborhood has a cereal-based diet dominated mainly by teff and maize which represent 63 percent of the total amount of food items consumed by the family in a week. The consumption of vegetables and fruits represents about 5 percent of the total amount of all food items while the quantity of pulses (beans and peas) accounts for 9 percent of the total amount of food consumed by the household in a week. Notice that products of animal origin were not consumed at all (zero percent of total amount consumed). However, final conclusions cannot be drawn given the small size sample of households reported in the survey.

In brief, the survey results indicate a lack of diversity of food items consumed and hence a low-quality nutrition. Diets predominantly based on starchy staples and cereals but poor in micronutrients are characteristic of food insecurity and contribute to malnutrition. ${ }^{[31,49]}$ Other aspects of food security relate to food availability, accessibility and stability at the household level. The baseline scenario summary results indicate adequate access and availability of calorific diets but does not assure future access and availability of other types of nutrients such as proteins, fat, calcium, iron, and vitamin A.

\subsection{Economic indicators simulation and food purchase options}

The evaluation of food security and nutrition is based both on the amount of food produced and consumed on the farm by the household and that acquired by purchase at the market, depending on cash availability. Also dietary diversity and nutritional status are good indicators of the household socioeconomic status where families with higher income are more likely to consume more diverse diets than poor households. ${ }^{[49]}$ Simulation of the baseline and alternative scenarios informs about the cash availability and nutritional quantities of calories, protein, fat, calcium, iron and vitamin A that are available to the household.

The economic indicators in Table 1 show a higher average net present value (NPV) for ALT1 than in any other scenario; ALT1 involves the use of a pulley to irrigate vegetables and fodder in the dry season in addition to growing potatoes and chickpeas. In ranking, it is followed by ALT4 related to the use of a pulley to irrigate and grow vegetable and fodder but with the exclusion of potatoes and chickpeas in the mix. Notice that ALT2, which does not consider growing vegetables, has the lowest average NPV. Similar results are observed for the net cash farm income (NCFI) which represents the cash profit at the household level. ALT1 and ALT4 have the highest average cash profit compared to other scenarios. 
Table 1. Economic impacts of SSI technologies in Robit kebele.

\begin{tabular}{|c|c|c|c|c|c|}
\hline & Baseline & ALT1_P_All & ALT2_P_NoVeg & ALT3_P_NoFod & ALT4_P_NoPC \\
\hline \multicolumn{6}{|l|}{ Values are in ETB / family/year } \\
\hline Net present value (5 yrs.) & 129,415 & 175,234 & 120,162 & 171,119 & 172,373 \\
\hline Avg. net cash income in year 5 & 21,265 & 29,902 & 15,814 & 29,061 & 29,787 \\
\hline min net cash income in year 5 & 2,375 & 7,188 & $-5,090$ & 8,965 & 7,093 \\
\hline max net cash income in year 5 & 66,356 & 76,572 & 58,071 & 78,612 & 76,460 \\
\hline
\end{tabular}

Note: numbers in red indicate losses or deficits; $\mathrm{ETB}=$ Ethiopia Birr $(1 \mathrm{USD}=21 \mathrm{ETB})$; $\min .=$ minimum, $\max .=\operatorname{maximum}$; avg. $=$ average Legend:

Baseline: current fertilizer + no or minimal irrigation;

ALT1_P_All: irrigate tomato, cabbage \& fodder with pulley + Potato \& chickpeas + recommended fertilizer

ALT2_P_NoVeg: irrigate fodder with pulley + No vegetable + Potato \& chickpeas + recommended fertilizer

ALT3_P_NoFod: irrigate tomato, cabbage with pulley+ No fodder + Potato \& chickpeas + recommended fertilizer

ALT4_P_NoPC: irrigate tomato, cabbage \& fodder with pulley + No potato \& chickpeas + recommended fertilizer

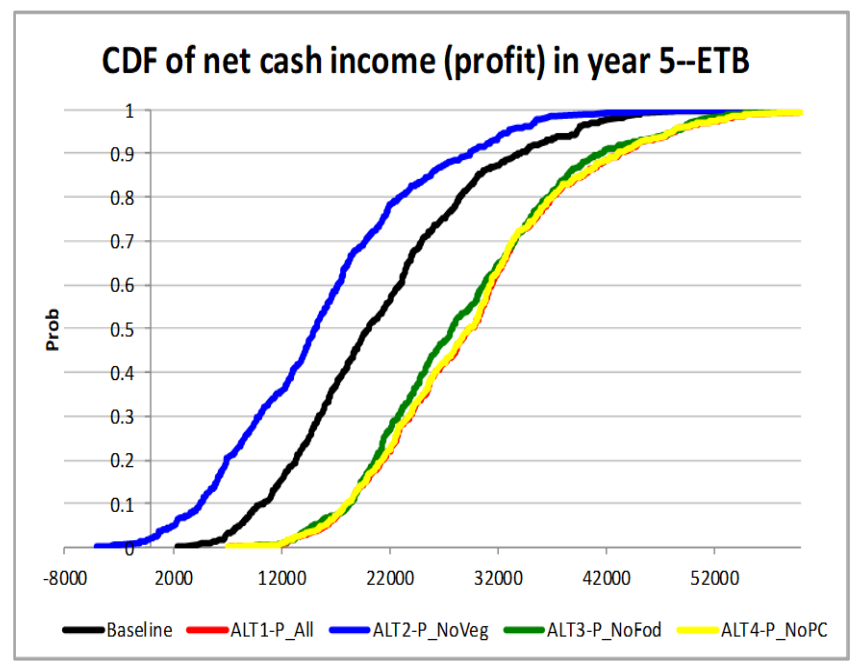

Fig. 2 CDF of NCFI in year 5 for Robit kebele, Amhara region.

It is worth noting that ALT2, which does not include growing vegetables, has the lowest average cash profit, ranking behind the baseline scenario. The simulation results based on the cumulative distribution function chart (Fig. 2) show that the alternative scenarios ALT1, ALT4 and ALT3 generated higher net cash farm income (NCFI) than the baseline and ALT2 at all probability levels. The results show that adding vegetables to the crop mix resulted in large profit gains that households could generate by irrigating, producing and selling vegetables during the dry season. Notice that the removal of fodder (ALT3-NoFod) or potatoes and chickpeas (ALT4-NoPC) in the crop mix does not seem to affect revenues as the cultivated land loss is much smaller, compared to the scenario that excludes vegetables (ALT2) (Appendix B). With enough cash profit at hand, farm families adopting ALT1, ALT3 and ALT4 can afford to purchase supplemental food items for nutrition. The main potential food items purchased by the farm family consisted of animal products such as meat (beef and chicken), milk and eggs due to the low consumption of these products by households in Robit (Appendix E1), in addition to purchasing rice and pinto beans (Appendix E2).

\subsection{Nutrition indicators simulation}

Nutrition simulation results show that the quantities of crops and livestock consumed by households in Robit kebele met minimum daily requirements for calories, proteins, iron and vitamin A but were insufficient for calcium and fat in both the baseline and alternative scenarios (Table 2). Moreover, the LIVES household survey indicates that individual households did not currently (Baseline scenario) purchase large quantities of food or receive any food aid to supplement the food they produce. However, in some of the alternative scenarios, a fraction of the total net cash available (about 10 percent) was considered for the purchase of supplemental food. It is worth mentioning that additional quantities of foodstuff from animal origin consumed at home were made available as well due to the improvement in animal productivity that targeted the increase in meat and milk production (see description above in section 3.3). For instance, with improved animal feeding, milk production (yield) increased by about 70 percent and the family consumption fraction of milk increased by 10 percent (Appendix D). The increased consumption of eggs, milk and meat in alternative scenarios under purchase options translated to significant improvement in proteins, fat, calcium, iron andvitamin A nutrient intake (Table 3). Note that the farm level nutrition simulation analysis in FARMSIM reflects strictly the availability and accessibility by the household of the six food nutrients above mentioned.

Table 2. Nutritional outcome of SSI technologies in Robit kebele. 


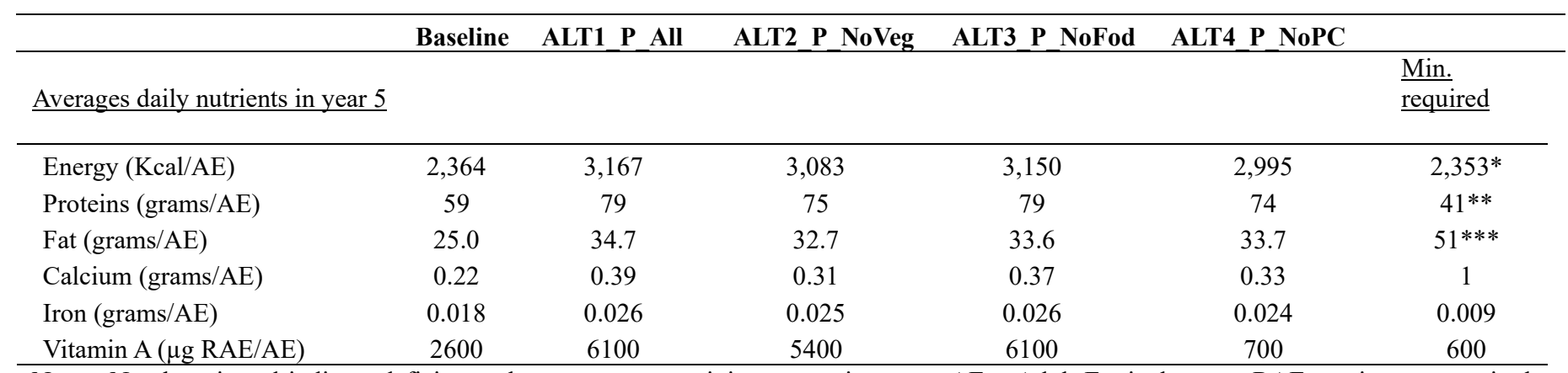

Notes: Numbers in red indicate deficits or shortage to meet minimum requirements; $\mathrm{AE}=$ Adult Equivalent; $\mu \mathrm{g}$ RAE $=$ microgram retinol activity equivalent (RAE) / day /person.

* The value for minimum requirement in energy is difficult to determine as the estimated energy requirement is defined as the average dietary intake that is predicted to maintain energy balance in a healthy adult of a defined age, gender, weight, height, and a level of physical activity ${ }^{[41]}$ For this reason we used the average dietary energy requirement (ADER) of 2,353 Kcal/person/day computed from FAO/WHO, 2001a ${ }^{[40]}$ and considered as the global average calorific intake required for a healthy life (Berners-Lee et al., 2018):DOI: https://doi.org/10.1525/elementa.310.

**For protein requirements, the dietary reference intakes (DRIs) for total proteins recommends an average intake of $0.66 \mathrm{~g} / \mathrm{Kg}$ of body weight / day. This number was multiplied by an average body weight of $62 \mathrm{Kgs}$ for male and female aged between 19-30 years-old (Institute of Medicine, 2006). ${ }^{[41]}$

***For fat requirements, with a range of $20-35 \%$, the minimal requirement for total dietary fat for an adult considered is $20 \%$ of total energy consumption. For a global average adult requiring $2,353 \mathrm{Kcal} /$ day and given the fat caloric content of $9 \mathrm{Kcal} / \mathrm{g}$, the total minimum fat requirement is: $(2,353 \mathrm{Kcal} / 9 \mathrm{Kcal} / \mathrm{g}) * 20 \%=51 \mathrm{~g} /$ day. $^{[39]}$

Table 3. Change in average nutrient intake for alternative scenarios under purchase option.

\begin{tabular}{|c|c|c|c|c|c|c|}
\hline \multirow{2}{*}{$\begin{array}{l}\text { Nutrients intake } \\
\text { available (grs/AE) }\end{array}$} & \multirow[b]{2}{*}{ Baseline } & \multicolumn{3}{|c|}{ Purchase scenarios } & \multirow{2}{*}{$\begin{array}{c}\text { No purchase scenario } \\
\text { ALT } 2\end{array}$} & \multirow{2}{*}{$\begin{array}{l}\text { \% change in nutrient } \\
\text { from Baseline to Alt. } \\
\text { scenario with purchase }\end{array}$} \\
\hline & & $\begin{array}{l}\text { ALT } 1 \\
\text { (eggs }\end{array}$ & $\begin{array}{l}\text { ALT } 3 \\
\text { chicken }\end{array}$ & $\begin{array}{l}\text { ALT } 4 \\
\text { \& beef) }\end{array}$ & & \\
\hline Proteins (grs/AE) & 59 & 79 & 79 & 74 & 75 & $31 \%$ \\
\hline Fat (grs/AE) & 25.0 & 34.7 & 33.6 & 33.7 & 32.7 & $36 \%$ \\
\hline Calcium (gr/AE) & 0.22 & 0.39 & 0.37 & 0.33 & 0.31 & $65 \%$ \\
\hline Iron (grs/AE) & 0.018 & 0.026 & 0.026 & 0.024 & 0.025 & $40 \%$ \\
\hline Vitamin A ( $\mu \mathrm{g}$ RAE/AE) & 2600 & 6100 & 6100 & 700 & 5400 & $65 \%$ \\
\hline
\end{tabular}

Simulation results for each of the nutrition indicator are discussed below in details.

For available calories intake, the simulation results indicate an average daily intake of 2,364 and 3,100 Calories (Table 2), respectively for the baseline and alternative scenarios, which are higher than the daily minimum requirement of 2,353 Calories per adult equivalent (AE). Larger land allocation to grain crops compared to other crops (Appendix B and $\mathrm{C} 2$ ), better management practices and the use of fertilizer contributed to a higher grain production and mitigated on average the deficiency in calories for the baseline and alternative scenarios. Survey information shows that, on average, 72 percent of all grains produced by a household in Robit are consumed at home. However, the simulation results indicate that households under the baseline scenario have a 43 percent chance of their calories intake being less than the required minimum of 2,353 Kcal/AE/day (Appendix F1). They also indicate that consumption of maize, millet and teff provided 82 percent of total calories in both scenarios for a representative household in Robit kebele with maize alone accounting for 70 percent.
The protein simulation results show that on average a representative household in the baseline and alternative scenarios has 59 and 79 grams/AE respectively of protein intake available which meet and exceed the daily minimum requirement of $41 \mathrm{gr} / \mathrm{AE}$ (Table 2 and Appendix F2). There is also a significant improvement in protein intake by 31 percent for the alternative scenarios compared to the baseline due to the increase in production and consumption of food with high protein content linked to the adoption of livestock and crop technologies and purchase (Table 3). Household surveys showed that the majority of the protein intake in Robit were from grain crops (70 percent) rather than animal products (3 percent). Maize and pinto beans alone contributed 63 percent of the total protein intake for a household in Robit kebele. It is a general pattern in developing countries, including Ethiopia, where the per capita consumption of livestock products is extremely low. ${ }^{[50]}$

Simulation results for fat intake show a deficit in fat intake for both the baseline and alternative scenarios (Table 2 and Appendix F3). Although there is an improvement of fat intake available between the baseline and the alternative scenarios, 
their respective averages of 25 and 33.6 grams are still below the average daily minimum fat requirement of 52 grams for an adult. The best performing alternative scenario (ALT1) provided on average 34.7 grams of fat per day per adult equivalent. As noticed with other nutrients, maize contributed alone about 66 percent of the total available household fat intake while animal source products (butter, beef and milk) contributed about 15 percent of total fat intake. Note that, through purchase, animal source products contribution to fat intake in alternative scenarios increased by 36 percent compared to the baseline scenario (Table 3 ).

The simulation results for available calcium intake show large deficits in for both the baseline and alternative scenarios (Table 2 and Appendix F4). The average calcium intake per $\mathrm{AE}$ is 0.22 and 0.38 grams, respectively, for the baseline and the two-best performing alternative scenarios (ALT1 and ALT3), falling short of the daily minimum requirements of 1 gram per AE. The large and consistent gap in calcium intake in the current study may reflect the existing concern regarding low calcium intake observed in developing countries (vs. developed countries) due to low animal products access and consumption. ${ }^{[38], ~[51]}$ Calcium may be of concern given the difficulty to meet its recommended nutrients intake (RNI) without the consumption of dairy products for both adults and children. ${ }^{[38,52]}$ Moreover, due to a mismatch between the calcium intake data and the relatively high intake requirements, a revised US/Canada Dietary Reference Intakes (DRIs) recommends replacing the Recommended Daily Allowance (RDA) with the Acceptable Intake (AI) calcium. Another concern on calcium threshold requirements relates to the wide difference between gender and age, making it difficult to find an acceptable average requirement. Unlike other nutrients discussed above, calcium came mainly from the consumption of pinto beans, milk and teff, which contributed 60 percent of total available calcium intake, with pinto beans alone contributing 26 percent of total intake. Note that the calcium intake quantity available at home increased by 65 percent from the baseline to the alternative scenarios (Table 3 ) due in part to milk purchase and production, as the quantity consumed at home doubled and contributed about 14 percent of total calcium intake.

This study analyzes the available iron intake as well at the household level through the consumption of food items produced and purchased. Simulation results indicate that households in Robit get more than the required minimum levels of iron. The average iron intake available per AE for all scenarios, estimated at 0.023 grams was more than twice the daily minimum requirement of 0.009 grams per AE (Table 2 and Appendix F5). There was also a significant improvement between the baseline and the alternative scenarios in terms of iron available, which averaged 0.18 and 0.25 grams respectively. Maize was the main provider of iron, contributing 58 percent of the total available iron intake to the household followed by pinto beans, with 15 percent contribution of iron. Iron deficiency is more predominant in developing countries and tends to become a chronic malnutrition issue even in grown children when iron is supplemented rather than provided in a balanced diet. ${ }^{[52]}$

The simulation results for vitamin $\mathrm{A}$ indicate adequate to surplus vitamin A intake levels in both the baseline and alternative scenarios. The average levels of vitamin A intake for the baseline and alternative scenarios (excluding ALT4) are $2600 \mu \mathrm{g}$ RAE and $5700 \mu \mathrm{g}$ RAE respectively, and 4 to 9 times higher than the daily minimum requirement for an adult equivalent of $600 \mu \mathrm{g}$ RAE (Table 2 and Appendix F6). Notice the low vitamin A intake levels (close to the minimum required) simulated under ALT4, which did not include potatoes and chickpeas in the crop mix. Potato and tomatoes were the main sources of Vitamin A, contributing around 98 percent of the total vitamin A intake available to the household. Very limited contribution came from the animal source products. Generally, cereal-based diets, which contain low concentrations of carotenoids compounds, a precursor of vitamin A, are characteristic of a low vitamin A intake and deficiency at the household level..$^{[9]}$ The inclusion and consumption of vegetables such as carrots, lettuce and kale could increase substantially the vitamin A intake available in Robit.

\section{Discussion}

Fighting food insecurity and improving nutrition start with the increase in quantity and variety of food production coupled with the consumption of a balanced diet. The adoption and appropriate use of irrigation technologies, specifically smallscale irrigation technologies, contributed to an increase in the quantity and variety of crops produced at the household level. Simulated total cultivated area in Robit increased on average by 20 percent due to the increased irrigated area (Appendix B). This allowed a dry season production of vegetables (tomatoes and cabbage), chickpeas, potatoes, and fodder which most of them doubled their cultivated area. The land increase combined with improved productivity (yield) due to the use of fertilizers and other agricultural management practices such as deep tillage, led to the increases in production.

For example, it is estimated that the amount of tomatoes, cabbage and potatoes production at the household level increased two to three-fold between the baseline and alternative scenario (ALT.1, 3 \& 4) (Appendix C2.). A significant improvement in fodder production under the alternative scenarios shows 8.4 times increase from the baseline. These results confirm findings from other studies, for example by Aseyehegn, Yirga and Rajan who found that in Ethiopia, farmers using irrigation systems produced crops twice, and sometimes even three times per year. ${ }^{[20]}$

Moreover, the increase in dry season crop production led to an increase in the amount of food available at the household level. For example, the amount of tomatoes and cabbage, available to the household under the alternative scenario (ALT1), increased by 52 percent and 170 percent respectively from the baseline while the increase was between 85 percent and 140 percent for chickpeas and potatoes (author's 
calculations from simulated values).

The increase in vegetable production under alternative scenarios (ALT1., ALT3 and ALT4.) led to a surplus that was sold at the market for income generation. The total potential quantity of vegetable surplus sold at the market under the alternative scenario (ALT1.) was 2.7 to 3.7 higher than that of the baseline, generating 2 to 3 times higher income at the household level. With extra cash on hands, households were allowed, in the simulation modeling, to use around 10 percent of total profit for supplemental food purchase that consisted mainly of products of animal source such as milk, eggs and meat (Appendix E2). Also, the contribution from improved animal production technology with feeds shows a small improvement in production of milk and meat. Although the contribution of animal source foods increased slightly the potential available nutrient intake for fat and calcium, the most improvement and increase came from maize and pinto beans with outstanding contribution to all the nutrients.

The use of improved animal production technologies (feeds and breeds) or the purchase of food products like milk, eggs and meat are one of the options to increase the variety and consumption of foods from animal sources to close the deficit in calcium and fat at the household level. The comparison of different alternative technology scenarios, whether it is through improved animal or vegetable production, shows that the income path may have higher potential impacts on nutrition for the farm family than production. For example, the removal of fodder in the crop mix (ALT3) did not have a major impact on nutrition and income compared to the removal of vegetables (ALT2) due to substantial reduction in income under ALT2. In other words, the contribution to milk and meat production through animal feeding had less impact on household nutrition than purchasing animal product items using profit from vegetable sale. These findings are corroborated by other research studies in Ethiopia and Tanzania by Passarelli et al. ${ }^{[21]}$ and Headey et al. ${ }^{[27]}$

Overall nutrition simulation results show adequate daily access (and surplus) to calories, proteins, iron and vitamin A per adult equivalent but a deficit in availability and access to calcium and fat at the household level in Robit kebele. However, they showed as well that increased consumption of animal source foods (e.g. milk, eggs) can effectively close the nutrition gap in fat and calcium intake.

Several nutrition professionals and researchers recommend a food and community-based approach as a sustainable way for combatting hunger and malnutrition in which fruits and vegetables are incorporated in a balanced family diet to provide vitamins and minerals. ${ }^{[38]}$ For instance, the home gardening approach that integrates gardening and nutrition education led by community leaders may be more beneficial and sustainable than quick and short-term interventions based on mineral or vitamin supplements. Home gardening, like the case of vegetables and fodder illustrated in this study, allows diet diversity through production and purchase ensuring that households access the appropriate set of nutrients needed for a healthy diet. Note that these results reflect the daily potential available nutrients per adult and do not disaggregate among gender and age within the household. Therefore, the study does not cover the issues of diet requirements for women or children but informs on the availability and accessibility of the six nutrients to households in Robit kebele.

\section{Conclusions}

A baseline scenario with minimal irrigation and current food consumption is compared to four alternative scenarios that benefited from irrigation and fertilizer to produce vegetables and fodder. These scenarios are aligned with four different consumption levels. Current food consumption and nutrient intake by a representative household in Robit indicates a satisfactory consumption and intake of calories from a cerealbased diet dominated by teff and maize. However, under the baseline scenario, the consumption of fruits, vegetables, pulses and animal source products is limited. There is an evident lack of food diversity and quality diet.

Alternative scenario one (ALT1) where vegetables and fodder are produced with irrigation in addition to potatoes and chickpeas, shows the highest nutritional benefits. Besides providing a variety of vegetables consumed at home, profits from vegetable sales were used to purchase supplemental food items such as milk, meat, and eggs. ALT1 also had the highest diet diversity that comprised cereals, vegetables, pulses, tubers, beef, milk, and eggs. Although simulation results show that the baseline and ALT1 scenarios meet the daily minimum required intake per adult equivalent for calories, proteins, iron and vitamin A, they both fall short in meeting minimums for fat and calcium. However, the results show a significant increase from the baseline to ALT1 in intake by 31 and 65 percent respectively for fat and calcium.

Among the three remaining alternative scenarios (ALT2, ALT3 and ALT4), ALT2 was the least performing scenario with the lowest amount of nutrients intake available and cash profit. ALT2 assumes the removal of vegetable production in the crop mix, which significantly reduced household profit, and the potential to purchase supplemental food. Moreover, under ALT2, the household access to vegetable consumption dropped as well leaving the family with fewer options to consume vegetables, and a less diversified diet. ALT3 and ALT4 scenarios which assumed the removal in the crop mix of fodder (and subsequent reduction in consumption of animal products), potatoes and chickpeas, performed fairly well in providing adequate nutrients to the household. However, the removal of potatoes and chickpeas in the crop and food mix reduced the availability of iron and vitamin A. The introduction of small-scale irrigation technologies allowed farmers to grow more crops which not only increased the cash profit at the household level but also the food diversity. This study provides an insight into the potential of households in Ethiopia to use improved technologies to reduce food insecurity and improve nutrition through food production and purchase. 


\section{Acknowledgements:}

This research was made possible and funded through the Feed the Future program by the United States Agency for International Development (USAID), Washington, DC [Grant number: AID-OAA-A-00055].

The authors wish also to acknowledge the following agencies and individuals who were instrumental in providing data and expert advice. The Innovation Lab for Small Scale Irrigation (ILSSI) team at Texas A\&M University: Abeyou Wale Worqlul, Yihun Dile Taddele, Henry Bryant, Brian Herbst, Raghavan Srinivasan Tom Gerik and Nicole Lefore; the International Livestock Research Institute (ILRI); the International Food Policy Research Institute (IFPRI); the International Water Management Institute (IWMI). Special thanks to Dr. Azage Tegegne and Dr. Berhanu Gebremedhin (ILRI-LIVES) in Ethiopia for sharing Robit household survey data.

\section{Conflict of interest:}

There are no conflicts to declare

\section{Supporting Information:}

Not Applicable.

\section{Abbreviations \\ AE: Adult equivalent \\ AI: Acceptable Intake \\ CDF: Cumulative distribution function \\ DAP: Diammonium phosphate \\ DRI: Dietary reference intakes \\ FAO: Food and Agriculture Organization \\ GHI: Global Hunger Index}

IFPRI: International Food Policy Research Institute

ILRI: International Livestock Research Institute

ILSSI: Innovation Laboratory for Small-scale Irrigation

IWMI: International Water Management Institute

KOVs: Key output variables

LIVES: Livestock and Irrigation Value Chains for Ethiopian

Smallholders

MDR: Minimum daily requirements

NCFI: Net cash farm income

NPV: Net present value

OECD: Organization for Economic Cooperation and

Development

RDA: Recommended daily allowance

RNI: Recommended nutrients intake

SIMETAR: Simulation and econometrics to analyze risk

SSA: Sub-Saharan Africa

SSI: Small-scale irrigation

USAID: United States Agency for International Development

\section{References}

[1] J. K. von Grebmer, J. Bernstein, D. Nabarro, N. Prasai, S. Amin, Y. Yohannes, A. Sonntag, F. Patterson, O. Towey, and J. Thompson, "Global Hunger Index: The Getting to zero hunger,"
2016.

[2]J. L. Leroy, M. Ruel, E. A. Frongillo, J. Harris, and T. J. Ballard, Food Nutr. Bull., 2015, 36, 167-195, doi: $10.1177 / 0379572115587274$.

[3] International Food Policy Research Institute (IFPRI), Global Nutrition Report 2015: Actions and accountability to advance nutrition and sustainable development, 2015.

[4] FAO, IFAD, UNICEF, WFP, and WHO, "The State of Food Security and Nutrition in the World 2017. Building Resilience for Peace and Food Security," Rome, FAO, 2017.

[5] C. B. Barrett, Science,2010, 327, 825-828, doi: 10.1126/science. 1182768 .

[6] L. Domenech and C. Ringler,IFPRI Discussion Paper 01259, SSRN Electron. J., 2013, doi: 10.2139/ssrn.2249812.

[7] Y. and P. M. von Grebmer, Klaus, Saltzman, Amy, Birol, Ekin, Wiesmann, Doris, Prasai, Nilam, Yin, Sandra, Yohannes, "2014 Global HunGer Index: The Challenge of Hidden Hunger," 2014.

[8] S. Muthayya, J. H. Rah, J. D. Sugimoto, F. F. Roos, K. Kraemer, and R. E. Black, PLoS One, 2013, 8, 1-12, doi: https://doi.org/10.1371/journal.pone.0067860.

[9] P. Shetty, "Addressing micronutrient malnutrition to achieve nutrition security," in Combating micronutrient deficiencies: food-based approaches, B. Thompson and L. Amoroso, Eds. FAO and CAB, 2011, pp. 28-40.

[10] R. E. Black and the Maternal and Child Nutrition Study Group, "Maternal and Child Nutrition: Executive Summary of The Lancet Maternal and Child Nutrition Series," 2013.

[11] M. Faber and S. Laurie, "A Home Gardening Approach Developed in South Africa to Address Vitamin A Deficiency," in Combating micronutrient deficiencies: food-based approaches, FAO and CAB, 2010, 163-182.

[12] J. Fletcher, "A guide to eating a balanced diet," Medical News Today, 2019.

[13] United Nations Office for the Coordination of Humanitarian Affairs (UNOCHA), "Weekly Humanitarian Bulletin - Ethiopia," 2016.

[14] Famine Early Warning Systems Network (FEWS NET), "Illustrating the extent and severity of the 2015 - 16 drought," 2015.

[15] T. Belachew, D. Lindstrom, A. Gebremariam, C. Jira, M. K. Hattori, C. Lachat, L. Huybregts, P. Kolsteren, BMC Public Health, 2012, 12, 1,doi: 10.1186/1471-2458-12-604.

[16] X. Diao and A. N. Pratt, Food Policy, 2007, 32, 205-228, doi: 10.1016/j.foodpol.2006.05.005.

[17] A. Motbainor, A. Worku, and A. Kumie, PLoS One, 2015, 10, 1-14, doi: 10.1371/journal.pone.0133542.

[18] A. Bogale, Ayalneh and Shimelis, African J. Food Agric. Nutr. Dev., 2009, 9, 1914-1926.

[19] H. Xie, L. You, B. Wielgosz, and C. Ringler, Agric. Water Manag., 2014, 131, 183-193, doi: 10.1016/j.agwat.2013.08.011.

[20] K. Aseyehegn, C. Yirga, and S. Rajan, J. Agric. Sci., 2012, 7, 43-57, doi: 10.5897/JSPPR.9000019.

[21] S. Passarelli, D. Mekonnen, E. Bryan, and C. Ringler, Food Secur., 2018, 10, 981-997, doi: 10.1007/s12571-018-0812-5. 
[22] M. W. Rosegrant, C. Ringler, and T. Zhu, Annu. Rev. Environ. Resour., 2009, 34, 205-222, ,doi: 10.1146/annurev.environ.030308.090351.

[23] N. J. Haselow, A. Stormer, and A. Pries, Matern. Child Nutr., 2016, 12, 155-168, ,doi: https://doi.org/10.1111/mcn.12260.

[24] A. Talukder, N. Haselow, A. Osei, E.Villate, D. Reario, H. Kroeun, L. SokHoing, A. Uddin, S. Dhunge, V. Quinn, F. Actions Sci. Reports. J. F. actions, 2010, 1, 0-9.

[25] R. S. Gibson, "Strategies for Preventing Multimicronutrient Deficiencies: a Review of Experiences with Foodbased Approaches in Developing Countries," in Combating micronutrient deficiencies: food-based approaches, B. Thompson and L. Amoroso, Eds. FAO and CAB, 2011, pp. 7-27. [26] R. E. Namara, M. A. Hanjra, G. E. Castillo, H. M. Ravnborg, L. Smith, and B. Van Koppen, "Agricultural water management and poverty linkages," Agric. Water Manag., 2010, 97, 520-527, doi: 10.1016/j.agwat.2009.05.007 .

[27] D. Headey, K. Hirvonen, J. Hoddinott, and D. Stifel, Am. J. Agric. Econ., 2019, 101, 1311-1327.

[28] G. Kennedy, T. Ballard, and M. C. Dop, "Guidelines for measuring household and individual dietary diversity," FAO, ROME, 2013.

[29] N. B. Ali, T. Tahsina, D. M. Hoque, M. M. Hasan, A. Iqbal, T. M.Huda, S. El Arifeen, PLoS One, 2019, 14, 1-18, doi: 10.1371/journal.pone.0221929.

[30] B. Thompson and L. Amoroso, "Preface," in Combating micronutrient deficiencies: food-based approaches, B. Thompson and L. Amoroso, Eds. FAO and CAB, 2011, pp. xixiii.

[31] G. Kennedy, M. Razes, T. Ballard, and M. C. Dop, "Measurement of dietary diversity for monitoring the impact of food based approaches," 2011.

[32] Federal Democratic Republic of Ethiopia, "Summary and Statistical Report of the 2007 Population and Housing Census," Published by the Population Census Commision, Addis Ababa, Ethiopia, 2008.

[33] Z. Wondatir, A. Adie, and A. J. Duncan, "Assessment of livestock production and feed resources at Robit Bata, Bahir Dar, Ethiopia,” ILSSI report: Nairobi, Kenya, ILRI., 2015.

[34] B. Gebremedhin, D. Hoekstra, A. Tegegne, K. Shiferaw, and A. Bogale, "Factors determining household market participation in small ruminant production in the highlands of Ethiopia," Nairobi, Kenya, 2015.

[35] Feed the Future Innovation Laboratory for Small Scale Irrigation (ILSSI), “Mid-Term Report, 2014-2016," College Station, TX, 2016.

[36] J. W. Richardson, K. Schumann, and P. Feldman, "Simetar: Simulation \& Econometrics to Analyze Risk," Department of Agriculturral Economics, Texas A\&M University, College Station, Texas., 2008.

[37] J. C. Bizimana and J. W. Richardson, Comput. Electron.
Agric., 2018, 156, 406-425, doi: 10.1016/j.compag.2018.11.038.

[38] Food and Agricultural Organization (FAO), "Human Vitamin and Mineral Requirements: Report of a joint FAO/WHO expert consultation," Food Nutr. Div., 2001, 303.

[39] Food and Agriculture Organization (FAO), "Fats and fatty acids in human nutrition: Report of an expert consultation," Food Nutr. Pap. 91, 2010, 180.

[40] Food and Agricutural Organization (FAO), "Human energy requirements: Report of a Joint FAO/WHO/UNU Expert Consultation," FAO Food Nutr. Tech. Rep. Ser., 2001,0, 96.

[41] Institute of Medicine, Dietary Reference Intakes: The Essential Guide to Nutrient Requirements. 2006.

[42] L. G. Bellu and P. Liberati, "Equivalence Scales: Subjective Methods," EASYPol: on-line resource materials for policy making, 2005. [Online]. Available: http://www.fao.org/docs/up/easypol/326/equv_scales_subjectmt d 033EN.pdf.

[43] Y. T. Dile and R. Srinivasan, J. Am. Water Resour. Assoc., 2014, 50, 1226-1241, , doi: 10.1111/jawr.12182.

[44] USAID (United States Agency for International Development), "Cost-Benefit Analysis of the Potatoes, Onions, and Tomatoes Value Chains in Ethiopia Graduation With Resilience To Achieve Sustainable Development ( Grad ) Project," Final Rep., 2013, 1-56,.

[45] D. K. Gebremeskel, “Assessment of Production Practice and Effect of N:P2O5:S Rates on Yield and Yield Components Of Head Cabbage (Brassica Oleracea var. capitata) Under Irrigation Conditions in Lay Armachio District, Amhara Region, Ethiopia," Bahir Dar University, 2016.

[46] C. B. Barrett, “Spatial Market Integration,” L.E. Blume, S.N. Durlauf, eds. The New Palgrave Dictionary of Economics, Second Edition, London: Palgrave Macmillan, Forthcoming, 2005, pp. 1-7.

[47] J. C. Bizimana, J. P. Angerer, D. A. Bessler, and F. Keita, J. Dev. Stud., 2015, 51, 319-334, doi: 10.1080/00220388.2014.963564.

[48] N. Key, E. Sadoulet, and A. De Janvry, Am. J. Agric. Econ., 2000, 82, 245-259, doi: 10.1111/0002-9092.00022

[49] M. Arimond and M. T. Ruel, J. Nutr., 2004, 134, 2579-2585, doi: $10.1093 / \mathrm{jn} / 134.10 .2579$.

[50] K. Tafere and I. Worku, "Consumption Patterns of Livestock Products in Ethiopia : Elasticity Estimates Using HICES ( 2004 / 05 ) Data," no. Essp Ii, 2004, 4-5.

[51] M. Agueh, V., Tugoué, M., Sossa, C., Métonnou, C., Azandjemè, C., Paraiso, N., Ouendo, M-E., Ouédraogo, L.T., Makoutodé, "Dietary Calcium Intake and Associated Factors among Pregnant Women in Southern Benin," Food Nutr. Sci., 2015 .

[52] M. H. Golden, Food Nutr. Bull., 2009, 30, 1-76, doi: $10.1177 \% 2$ F 15648265090303 S302. 


\section{Author information}

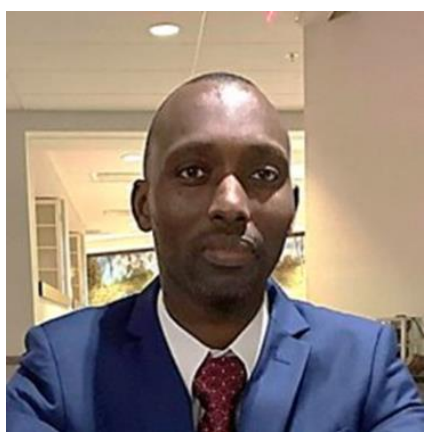

Jean-Claude Bizimana is an Associate Research Scientist in the Department of Agricultural Economics at Texas A\&M University currently working for the Feed the Future Innovation Laboratory for Small Scale Irrigation project. The project is funded by the USAID and implemented in Ethiopia, Ghana and Tanzania. His main research field relates to farm level simulation analysis using a Monte Carlo approach to evaluate economic and nutritional impacts of alternative technologies on family farms. He has more than 15 years of experience working in international agricultural and rural development sectors in Rwanda, Ghana, Ethiopia, Tanzania and Mali. Jean Claude received several awards including the 2019 BIFAD award for research excellence and is a 2012 AIARD Future Leader scholar. Jean-Claude Bizimana graduated with a BSc in Soil Sciences from the National University of Rwanda, an MSc in Agricultural Extension from Michigan State University and a PhD in Agricultural Economics from Texas A\&M University.

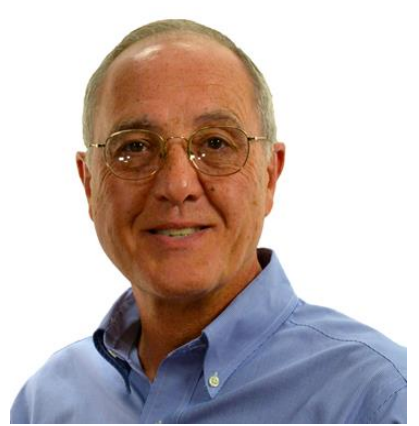

Dr. James W. Richardson is Professor Emeritus Department of Agricultural Economics at Texas A\&M University, and formerly Co-Director of the Agricultural and Food Policy Center, Texas A\&M AgriLife Senior Faculty Fellow, and Senior Regents Professor. Dr. Richardson received his Ph.D. in agricultural economics at Oklahoma State University in 1978 and joined the Texas A\&M Department of Agricultural Economics in 1978 where he taught risk analysis and conducted research on farm policy, risk analysis, and the economic feasibility of alternative feedstocks for renewable fuels. He has been repeatedly recognized for his research on farm policy analysis and developing risk-based simulation models for analyzing the benefits/costs of alternative farming systems, new technology, crop insurance, and policy changes on representative farms.

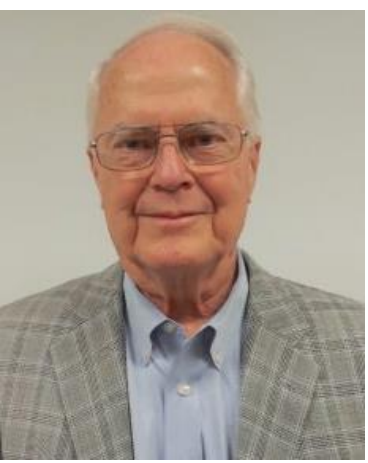

Dr. Neville P. Clarke is a special assistant for program development in the office of the vice chancellor of agriculture at Texas A\&M University. Dr. Clarke has been actively involved in international research on food and agriculture in several developing countries including Latina America and Africa with a focus on poverty alleviation and food security and served as director of several institutes and centers within AgriLife Research from 1996 to the present. Recently, Clarke was principal investigator and director of the US Agency for International Development's Innovation Laboratory for Small Scale Irrigation (2013-2018) and founding director of the U.S. Department of Homeland Security's National Center of Excellence on Foreign Animal and Zoonotic Disease Defense. He earned a doctorate in veterinary medicine from Texas A\&M and a master's and doctorate in physiology from the University of Washington School of Medicine.

Publisher's Note: Engineered Science Publisher remains neutral with regard to jurisdictional claims in published maps and institutional affiliations. 


\section{APPENDICES}

Appendix A. Flowchart of the nutrition simulation process in FARMSIM

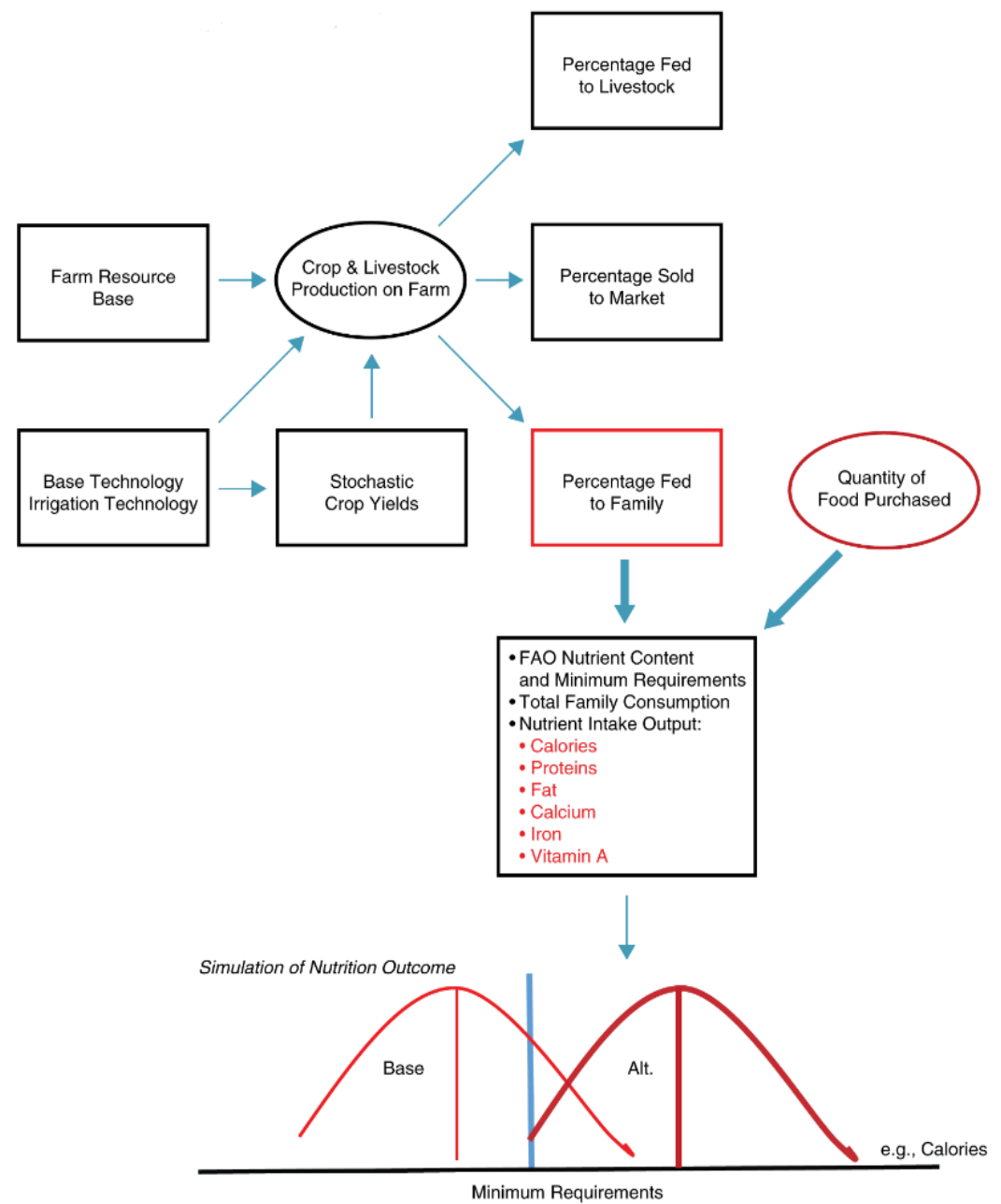

Appendix B. Crop mix and land allocation (ha) scenarios for Robit kebele.

\begin{tabular}{|c|c|c|c|c|c|c|c|c|c|c|c|}
\hline \multirow[t]{2}{*}{ Scenarios } & Millet & Teff & Maize & Chickpeas & Potato & $\begin{array}{l}\text { Irrigated } \\
\text { Cabbage }\end{array}$ & $\begin{array}{l}\text { Irrigated } \\
\text { Tomato }\end{array}$ & $\begin{array}{l}\text { Irrigated } \\
\text { Fodder }\end{array}$ & $\begin{array}{l}\text { Irrigated } \\
\text { Napier }\end{array}$ & \multirow[t]{2}{*}{ Total (ha) } & \\
\hline & & & \multicolumn{3}{|c|}{ Rainy season } & & \multicolumn{3}{|c|}{ Dry season } & & \\
\hline $\begin{array}{l}\text { Baseline } \\
\text { ALT.1 }\end{array}$ & 708.0 & 266.0 & 728.0 & 57.0 & 24.0 & 126.0 & 102.0 & 43.0 & 43.0 & $2,097.0$ & \\
\hline P_All & 708.0 & 266.0 & 728.0 & 110.0 & 50.0 & 228.0 & 204.0 & 145.0 & 63.0 & $2,502.0$ & 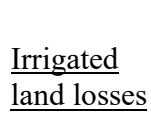 \\
\hline $\begin{array}{l}\text { ALT.2 } \\
\text { P_NoVeg } \\
\text { ALT.3 }\end{array}$ & 708.0 & 266.0 & 728.0 & 110.0 & 50.0 & 0.0 & 0.0 & 148.0 & 63.0 & $2,073.0$ & $-438 h a$ \\
\hline $\begin{array}{l}\text { P_NoFod } \\
\text { ALT.4 }\end{array}$ & 708.0 & 266.0 & 728.0 & 110.0 & 50.0 & 356.0 & 332.0 & 0.0 & 0.0 & $2,550.0$ & $-376 h a$ \\
\hline $\mathrm{P}$ NoPC & 708.0 & 266.0 & 728.0 & 0.0 & 0.0 & 240.0 & 216.0 & 157.0 & 63.0 & $2,378.0$ & $-160 h a$ \\
\hline
\end{tabular}

Legend:

Baseline: current fertilizer + no or minimal irrigation;

ALT.1_P_All: irrigate tomato, cabbage \& fodder with pulley + Potato \& chickpeas + recommended fertilizer

ALT.2_P_NoVeg: irrigate fodder with pulley + No vegetables + Potato \& chickpeas + recommended fertilizer

ALT.3_P_NoFod: irrigate tomato, cabbage with pulley+ No fodder + Potato \& chickpeas + recommend fertilizer

ALT.4_P_NoPC: irrigate tomato, cabbage \& fodder with pulley + No potato \& chickpeas + recommended fertilizer. 
Appendix C1. Current and recommended annual application rates of urea and DAP, Robit.

\begin{tabular}{|c|c|c|c|}
\hline \multirow{3}{*}{ Crops } & \multicolumn{3}{|c|}{ Fertilizer rates: Urea + DAP $(\mathrm{Kgs} / \mathrm{ha})$} \\
\hline & \multirow{2}{*}{$\begin{array}{c}\text { Baseline scenario } \\
\text { current } \\
\end{array}$} & \multicolumn{2}{|c|}{ Alternative scenario } \\
\hline & & Applied & $\underline{\text { Recommended }}$ \\
\hline Teff & 124 & 200 & 200 \\
\hline Maize & 200 & 200 & 200 \\
\hline Millet & 140 & 100 & 100 \\
\hline Tomato & 56 & 300 & 350 \\
\hline Cabbage & 8 & 140 & $250-300$ \\
\hline Chickpeas & 0 & 26 & - \\
\hline Potato & 23 & 160 & 350 \\
\hline Fodder (oats \& vetch) & 0 & 100 & - \\
\hline Napier grass & 0 & 100 & - \\
\hline
\end{tabular}

Appendix C2. Mean crop yields (Kg/ha), land area (ha) and input costs (Birr/ha) for scenarios in Robit.

\begin{tabular}{|c|c|c|c|c|c|c|c|c|c|c|c|c|}
\hline \multirow{3}{*}{ Crops } & \multicolumn{6}{|c|}{ Baseline scenario } & \multicolumn{6}{|c|}{ Alternative scenarios } \\
\hline & $\begin{array}{l}\text { Mean } \\
\text { yield }\end{array}$ & $\begin{array}{l}\text { Crop } \\
\text { area }\end{array}$ & $\begin{array}{l}\text { Cost } \\
\text { fert. }\end{array}$ & $\begin{array}{l}\text { Cost } \\
\text { seed }\end{array}$ & $\begin{array}{l}\text { Cost } \\
\text { irrig }\end{array}$ & $\begin{array}{l}\text { Other } \\
\text { labor }\end{array}$ & $\begin{array}{l}\text { Mean } \\
\text { yield }\end{array}$ & $\begin{array}{l}\text { Crop } \\
\text { area }\end{array}$ & $\begin{array}{l}\text { Cost } \\
\text { fert. }\end{array}$ & $\begin{array}{l}\text { Cost } \\
\text { seed }\end{array}$ & $\begin{array}{l}\text { Cost } \\
\text { irrig }\end{array}$ & $\begin{array}{l}\text { Other } \\
\text { labor }\end{array}$ \\
\hline & (Kgs/ha) & $\begin{array}{l}\text { /hh } \\
\text { (ha) }\end{array}$ & (Birr/ha) & (Birr/ha) & $\begin{array}{l}\text { labor } \\
(\text { Birr/ha) }\end{array}$ & $\begin{array}{l}\text { cost } \\
\text { (Birr/ha) }\end{array}$ & (Kgs/ha) & $\begin{array}{l}\text { /hh } \\
\text { (ha) }\end{array}$ & (Birr/ha) & (Birr/ha) & $\begin{array}{l}\text { labor } \\
\text { (Birr/ha) }\end{array}$ & $\begin{array}{l}\text { cost } \\
\text { (Birr/ha) }\end{array}$ \\
\hline Teff & 838 & 0.13 & 1614 & 470 & 0 & 172 & 1995 & 0.13 & 4800 & 470 & 0 & 172 \\
\hline Maize & 2127 & 0.36 & 4284 & 476 & 258 & 73 & 2773 & 0.36 & 4284 & 476 & 258 & 1350 \\
\hline Millet & 1640 & 0.35 & 3110 & 46 & 0 & 0 & 2257 & 0.35 & 3110 & 46 & 0 & 1350 \\
\hline Tomato & 14293 & 0.05 & 783 & 420 & 259 & 250 & 21714 & 0.10 & 1875 & 420 & 10757 & 4181 \\
\hline Cabbage & 11376 & 0.06 & 110 & 880 & 258 & 200 & 18089 & 0.11 & 110 & 880 & 10757 & 600 \\
\hline Chickpeas & 1274 & 0.02 & 358 & 122 & 258 & 0 & 1274 & 0.05 & 358 & 122 & 258 & 0 \\
\hline Potato & 3770 & 0.01 & 100 & 0 & 736 & 0 & 7728 & 0.02 & 1504 & 2595 & 736 & 1504 \\
\hline Fodder & 12654 & 0.02 & 0 & 300 & 258 & 0 & 34168 & 0.07 & 3000 & 1200 & 10757 & 0 \\
\hline
\end{tabular}

Notes: 1) fert. = fertilizer; irrig = irrigation; hh = household; O\&V= Oats \& Vetch; Exchange rate: 21 Birr (Ethiopian Birr) = 1 USD

2) Increase in "Other labor cost" in alternative scenarios are due to increased labor costs of breaking down the hardpan soil.

Appendix C3. Sources of FARMSIM input data.

\begin{tabular}{|c|c|c|c|c|c|}
\hline \multirow[t]{2}{*}{ Data category } & \multirow{2}{*}{$\begin{array}{l}\text { Type of crop, livestock, } \\
\text { financial data }\end{array}$} & \multirow[t]{2}{*}{ Type of input data } & \multicolumn{2}{|c|}{ Source of data and responsible institution } & \multirow{2}{*}{ Year } \\
\hline & & & Baseline scenario & Alternative scenario & \\
\hline Crop input data & $\begin{array}{l}\text { Millet, teff, maize, } \\
\text { tomatoes, potatoes, } \\
\text { cabbage. Fodder }\end{array}$ & $\begin{array}{l}\text { Ag input costs (seeds, labor, } \\
\text { fertilizers, irrigation), yield; } \\
\text { production use }\end{array}$ & $\begin{array}{l}\text { Baseline household } \\
\text { survey (LIVES } \\
\text { project) }\end{array}$ & Field survey (IWMI) & $\begin{array}{l}2014, \\
2015, \\
2016, \\
2017\end{array}$ \\
\hline $\begin{array}{c}\text { Livestock input } \\
\text { data }\end{array}$ & $\begin{array}{l}\text { Cattle, goat, sheep, } \\
\text { chicken, pork }\end{array}$ & $\begin{array}{l}\text { Fraction of livestock sold, } \\
\text { consumed, die; price per } \\
\text { head; annual expenses; }\end{array}$ & $\begin{array}{l}\text { Baseline household } \\
\text { survey (LIVES) }\end{array}$ & $\begin{array}{l}\text { Baseline household } \\
\text { survey (LIVES project) } \\
\text { + Field studies on } \\
\text { livestock nutrition and } \\
\text { productivity (ILRI) }\end{array}$ & $\begin{array}{l}2014, \\
2015 \\
2016 \\
2017\end{array}$ \\
\hline $\begin{array}{l}\text { Family fixed } \\
\text { costs }\end{array}$ & $\begin{array}{c}\text { Maintenance, insurance, } \\
\text { taxes, wages, household } \\
\text { expenses, school fees, } \\
\text { medical }\end{array}$ & Cost amount & $\begin{array}{l}\text { Baseline household } \\
\text { survey (LIVES } \\
\text { project) }\end{array}$ & $\begin{array}{l}\text { Baseline household } \\
\text { survey (LIVES project); } \\
\text { Field survey (IWMI) }\end{array}$ & $\begin{array}{l}2014 \\
2016 \\
2017\end{array}$ \\
\hline \multirow[t]{2}{*}{$\begin{array}{c}\text { Assets } \\
\text { liabilities }\end{array}$} & Land; tools; buildings & $\begin{array}{c}\text { Crop and pasture land owned; } \\
\text { value of machinery, land, } \\
\text { buildings }\end{array}$ & $\begin{array}{l}\text { Baseline household } \\
\text { survey (LIVES } \\
\text { project) }\end{array}$ & $\begin{array}{l}\text { Baseline household } \\
\text { survey (LIVES project); } \\
\text { Field survey (IWMI) }\end{array}$ & $\begin{array}{l}2014, \\
2016, \\
2017\end{array}$ \\
\hline & Loans & $\begin{array}{l}\text { Amount; interest rate; term } \\
\text { (years of repayment); }\end{array}$ & & & \\
\hline
\end{tabular}


Appendix D. Input variables and livestock technology scenarios in Robit kebele.

\begin{tabular}{|c|c|c|c|c|c|}
\hline & Baseline & ALT1 & ALT2 & ALT3 & ALT4 \\
\hline \multicolumn{6}{|l|}{ Cows } \\
\hline Native & 2640 & 2640 & 2640 & 2640 & 2640 \\
\hline Cross-bred & 165 & 165 & 165 & 165 & 165 \\
\hline \multicolumn{6}{|l|}{ Milk per cow } \\
\hline Liters/cow/year & 185 & 312 & 312 & 185 & 312 \\
\hline Live Weight gain (Kgs) & 0 & 52.4 & 52.4 & 0 & 52.4 \\
\hline $\begin{array}{l}\text { Live weight /bull } \\
\text { Consumption }\end{array}$ & 184 & 236.4 & $\begin{array}{l}236.4 \\
\text { Percent } \\
(\%)\end{array}$ & 184 & 236.4 \\
\hline Milk by family & 28 & 38 & 38 & 28 & 38 \\
\hline Milk by employees & 0 & 0 & 0 & 0 & 0 \\
\hline Milk made into butter & 70 & 50 & 50 & 50 & 50 \\
\hline Butter sold & 54 & 54 & 54 & 54 & 54 \\
\hline
\end{tabular}

Note: In alternative scenarios, cattle/cows were fed $1600 \mathrm{Kgs} / \mathrm{year} /$ head of fodder vs. $100 \mathrm{Kgs} / \mathrm{head} / \mathrm{year}$ for the baseline scenario leading to an increase in milk by 127 liters/year /head and $52.4 \mathrm{Kgs}$ of meat/year/head.

Appendix E1. Weekly average food quantity (Kgs) consumed by a household in Robit.

\begin{tabular}{ccccccccc}
\hline Food items & Hh \#1 & Hh $\# 2$ & Hh $\# 3$ & Hh $\#$ 4 & Hh $\# 5$ & Hh \#6 & Hh \#7 & $\begin{array}{c}\text { Avg. Qty. Food } \\
\text { /wk/Hh (Kgs) }\end{array}$ \\
\hline Teff & 4 & 0 & 14 & 18 & 10 & 10 & 4 & 8.6 \\
Maize & 10 & 10 & 24 & 30 & 24 & 10 & 10 & 16.9 \\
Rice/millet/barley & 6 & 0 & 0 & 0 & 6 & 0 & 4 & 2.3 \\
Beans & 4 & 4 & 0 & 0 & 0 & 4 & 4 & 2.3 \\
Peas/lentil & 4 & 5 & 0 & 0 & 1 & 0 & 0 & 1.4 \\
Fruits & 2 & 4 & 0 & 0 & 0 & 2 & 0 & 1.1 \\
Vegetables & 2 & 4 & 0 & 0 & 0 & 0 & 0 & 0.9 \\
Tubers & 4 & 6 & 0 & 0 & 0 & 0 & 0 & 1.4 \\
Animal products & & & & & & & 0 & 0.0 \\
(milk, butter, eggs & 0 & 0 & 0 & 0 & 0 & 0 & 0 & 1.4 \\
cheese, meat) & & & & & & & & 3.1 \\
Fish & 0 & 10 & 0 & 0 & 0 & 0 & 0 & 0.5 \\
Spices/pepper/salt & 2.5 & 2.5 & 3.5 & 4.5 & 1.5 & 2 & 5.5 & 0.7 \\
Sugar & 0.5 & 0.5 & 0 & 0.3 & 0 & 2 & 0 & 1 \\
Cooking oil & 0.5 & 0.5 & 0.5 & 0.5 & 1 & 1 &
\end{tabular}


Appendix E2. Food of animal origin consumed per year at village and household level—Robit.

\begin{tabular}{|c|c|c|c|c|}
\hline \multirow[b]{2}{*}{ Food items (Kgs) } & \multicolumn{2}{|c|}{ Baseline scenario } & \multicolumn{2}{|c|}{ Alternative scenarios } \\
\hline & Raised & purchased & Raised & purchased \\
\hline \multicolumn{5}{|c|}{ Village level $(1980 \mathrm{HH})$} \\
\hline Milk in $\mathrm{KG}$ & 49244 & 0 & 94368 & 30000 \\
\hline Eggs in $\mathrm{KG}$ & 5160 & 0 & 5160 & 5040 \\
\hline Chicken in $\mathrm{KG}$ & 4075 & 0 & 4075 & 2000 \\
\hline Beef in $\mathrm{KG}$ & 3478 & 0 & 3478 & 2000 \\
\hline Lamb in $\mathrm{KG}$ & 1712 & 0 & 1712 & 0 \\
\hline Goat Meat in $\mathrm{KG}$ & 30 & 0 & 27 & 3 \\
\hline Pig Meat in $\mathrm{KG}$ & 0 & 0 & 0 & 0 \\
\hline Butter in $\mathrm{KG}$ & 3432 & 0 & 4846 & 0 \\
\hline \multicolumn{5}{|c|}{ Household level $(1 \mathrm{HH})$} \\
\hline Milk in $\mathrm{KG}$ & 25 & 0 & 48 & 15 \\
\hline Eggs in $\mathrm{KG}$ & 3 & 0 & 3 & 3 \\
\hline Chicken in $\mathrm{KG}$ & 2 & 0 & 2 & 1 \\
\hline Beef in $\mathrm{KG}$ & 2 & 0 & 2 & 1 \\
\hline Lamb in $\mathrm{KG}$ & 1 & 0 & 1 & 0 \\
\hline Goat Meat in KG & 0 & 0 & 0 & 0 \\
\hline Pig Meat in KG & 0 & 0 & 0 & 0 \\
\hline Butter in $\mathrm{KG}$ & 2 & 0 & 2 & 0 \\
\hline
\end{tabular}

Appendix F. Cumulative distribution function of nutritional variables.

Appendix F1. Calories (or energy) intake distribution.

\section{CDF of daily energy consumption per adult (Kcal)}

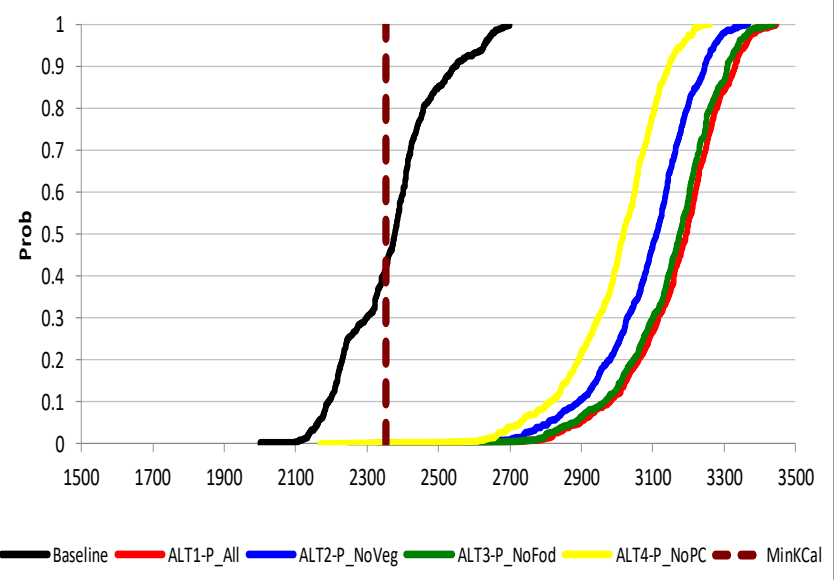

Appendix F2. Protein intake distribution.

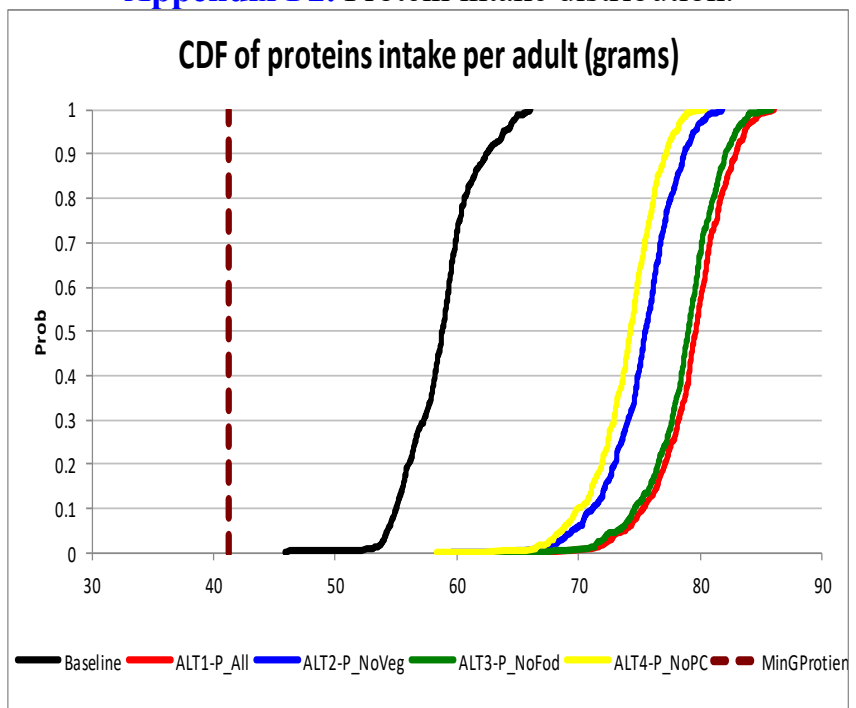


Appendix F3. Fat intake distribution.

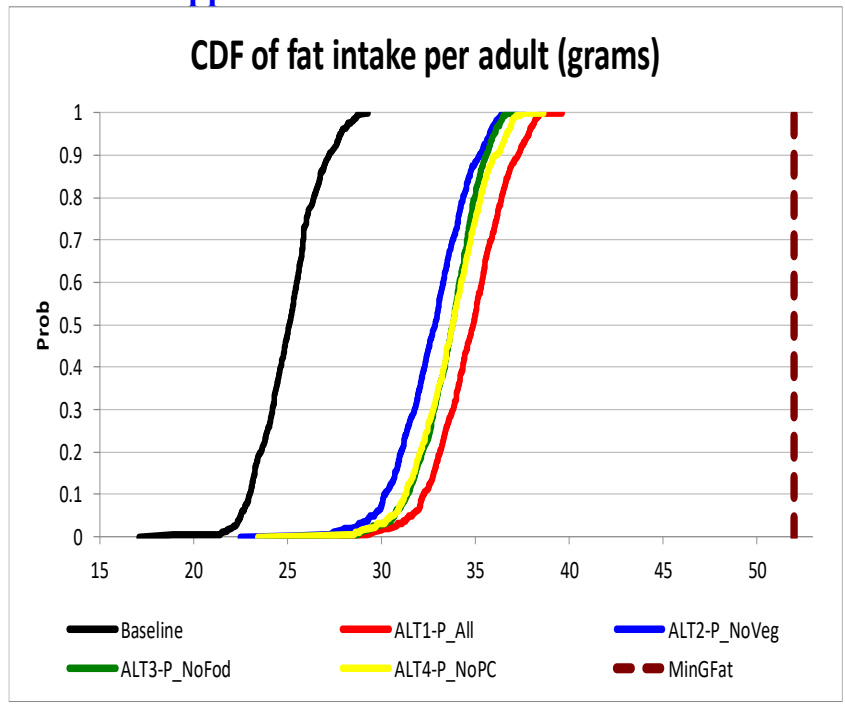

Appendix F5. Iron intake distribution.

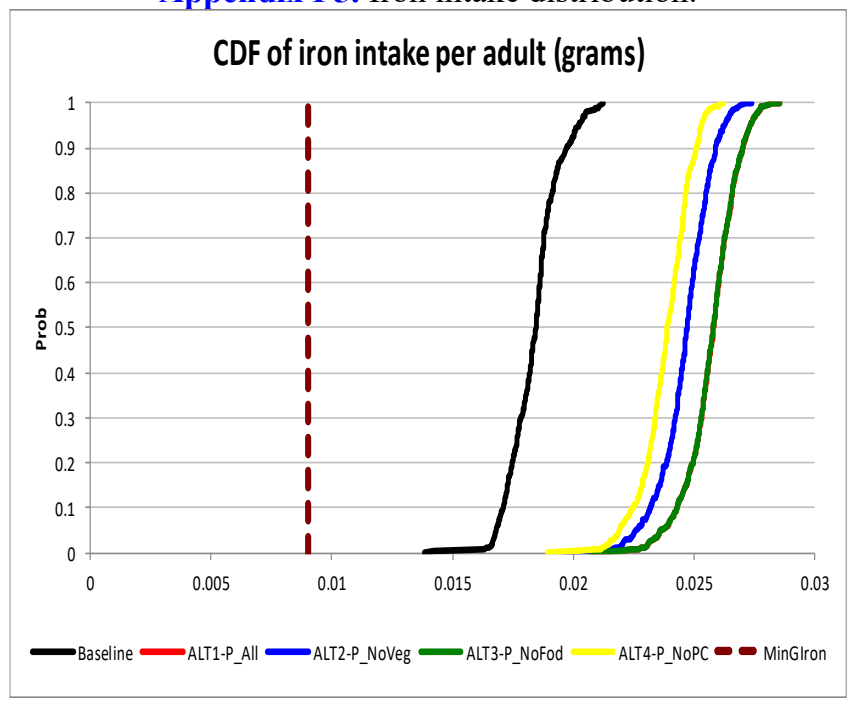

i Small-scale irrigation (SSI) technologies can be defined as small community-managed irrigation systems by individual or a group of farmers on small plots over which smallholder farmers have control and use a level of technology they can operate and maintain effectively (see Carter and Howsam, 1994)

ii Detailed information on the FARMSIM model can be found in a research report for the Robit kebele, Amhara region of Ethiopia that was carried out under the Feed the Future Innovation Laboratory for Small Scale Irrigation (ILSSI) https://www.afpc.tamu.edu/research/publications/683/FARM SIM.pdf

iii For more information on the surveys, see:

International Livestock Research Institute (ILRI)-Livestock and Irrigation Value Chains for Ethiopian Smallholders (LIVES) https://lives-ethiopia.org/2014/06/06/baselinesurveys/

International Food Policy Research Institute (IFPRI), 2015.
Appendix F4. Calcium intake distribution.

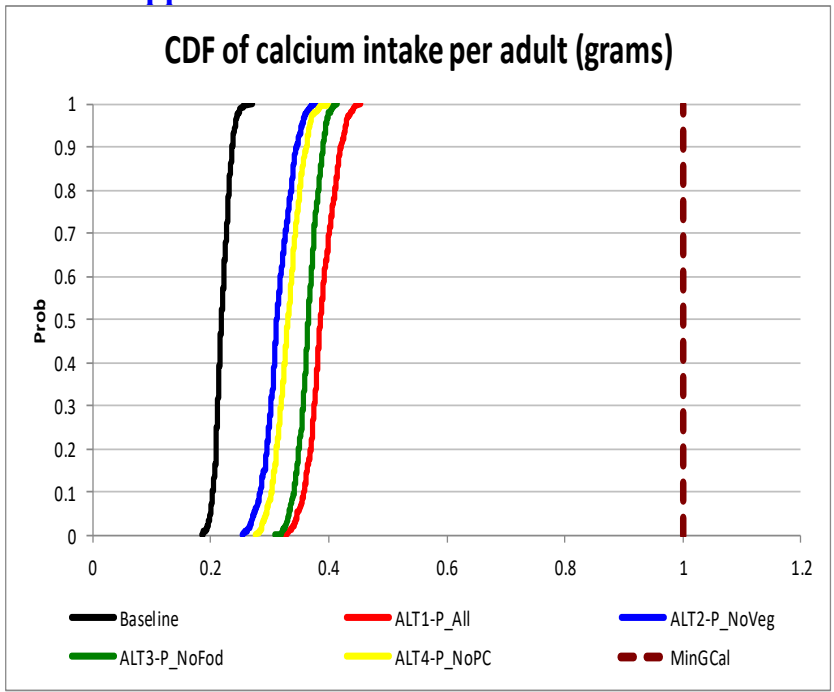

Appendix F6. Vitamin A intake distribution.

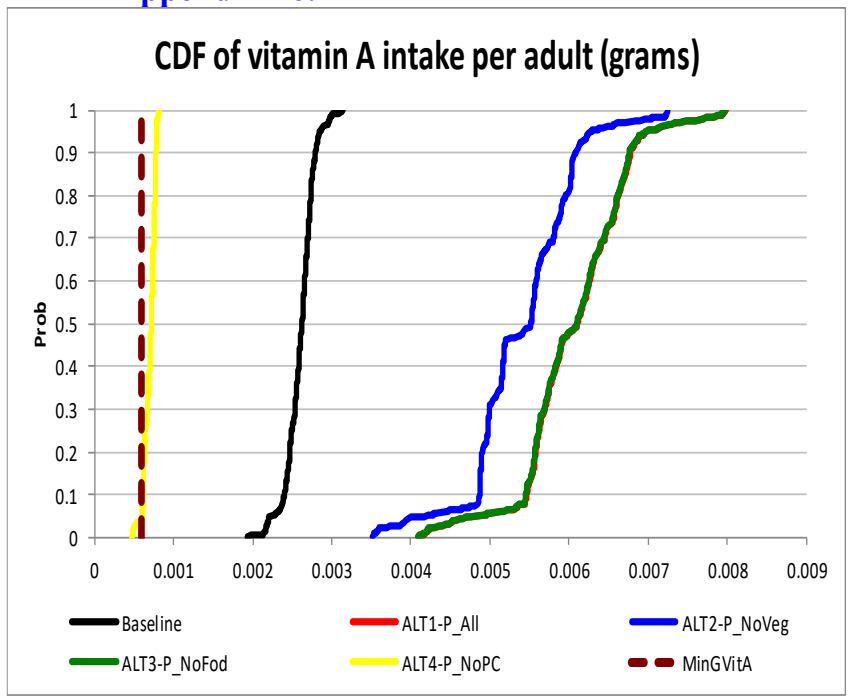

"ILSSI/IFPRI study on irrigation, gender, and nutrition", https://doi.org/10.7910/DVN/DH1O3J, Harvard Dataverse, V1.

iv Feed the Future- ILSSI-Report: Experimental and research design

Ethiopia, https://ilssi.tamu.edu/files/2019/12/19012015_ilssi_ethiopiaresearch-design-2.pdf

$v$ FARMSIM is a micro-computer simulation model that is programmed in Excel/Simetar, which is an enhanced version of FLIPSIM designed to simulate smallholder farms in developing countries (Richardson and Nixon, 1985). FLIPSIM has been used extensively for policy analysis and technology assessment for farms in the United States.

vi Extensive testing with the Latin Hypercube sampling procedure in Simetar has shown that a sample size of 500 iterations is more than adequate to estimate a probability distribution for KOVs in a business model with more than 100 random variables. 
vii We assert that the consumption fraction for different food crops found in the baseline survey reflects the approximate portion of own household production fraction consumed by family members. We maintained it for cereal crops in the alternative scenario due to low and limited increase in production and productivity, except for teff, due to technology. However, given the substantial increase in production and productivity of irrigated crops (tomatoes and cabbage) due to improved technology and land allocation, we adjusted the consumption rate to reflect the quantities that families required and consumed in the baseline scenario with small increments to give room for possible increase of quantity consumed. We can argue that doubling the quantity produced of a food crop does not necessarily result in doubling its consumption unless there is a substantial deficit in the amount consumed at home for that food crop. Our assertion is in part supported by a study by John W. Mellor (1986) which shows that the projected (1980-2000) average annual growth rate in production of major food crops in developing countries $(2.9 \%)$ was about the same as the projected average annual growth rate in consumption of major food crops (2.7\%). In Sub-Saharan Africa considered as less developed, the rate increased by $70 \%$ $(2.1 \%$ - production vs. $3.6 \%$ consumption) which is a characteristic of subsistence farming and food deficit. https://www.ncbi.nlm.nih.gov/books/NBK231290/?report=pr intable

viii Note that in case of a surplus in production households do not necessarily increase their fraction of the crop consumed unless there is a deficit in the baseline scenario that would require them to increase the amount consumed in the alternative scenario. Otherwise, consumption fractions in the alternative scenarios are adjusted to reflect the amount the household needs to consume and the rest is sold at the market. ix A couple resources are indicated in FAO, 2010 [1] and FAO, 2001 [37] but we also used several other literature sources on food composition tables to verify and check the accuracy of the nutrient values contained in different food crops and livestock products such as the West Africa Food Composition Table (FAO, 2012: http://www.fao.org/3/a-i2698b.pdf)

${ }^{x}$ Issue of hardpan soil in Robit is discussed in the report by the Bahir Dar University (BDU), a partner in the implementation of the ILSSI project: https://ilssi.wikispaces.com/file/view/Mid+Term+Report+Fe $\underline{b+2015 . p d f}$

Ri Report is available at: https://ilssi.tamu.edu/files/2019/11/annual-report-october-12015-september-30-2016.pdf

xii Given that there were no food consumption data collected on Robit kebele we used data from two other kebeles located near Robit on Lake Tana (Wenijata and Wegelsa kebeles). 